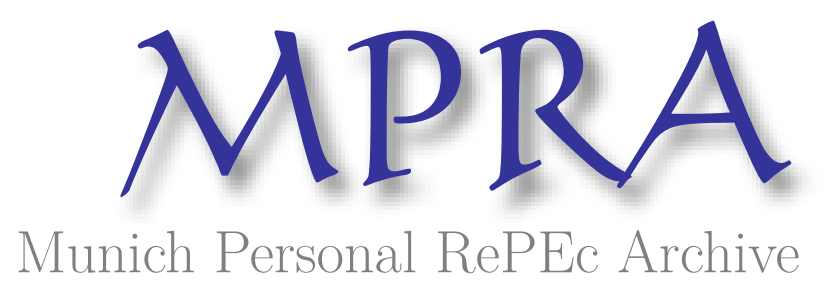

\title{
Distributional Effects of Corruption When Enforcement is Biased: Theory and Evidence from Bribery in Schools in Bangladesh
}

M. Shahe, Emran and Asadul, Islam and Forhad, Shilpi

17 February 2018

Online at https://mpra.ub.uni-muenchen.de/84637/

MPRA Paper No. 84637, posted 18 Feb 2018 09:54 UTC 


\title{
Distributional Effects of Corruption When Enforcement is Biased: Theory and Evidence from Bribery in Schools in Bangladesh
}

\author{
M. Shahe Emran ${ }^{1}$ \\ IPD, Columbia University \\ Asadul Islam \\ Monash University \\ Forhad Shilpi \\ World Bank \\ ABSTRACT
}

In many models of corruption where enforcement is unbiased and the official maximizes her income, the rich are more likely to pay bribes for their children's education, implying that corruption reduces educational inequality. We develop models of bribery that reflect the fact that, in developing countries, anti-corruption enforcement is not unbiased, and higher income of a household is associated with higher bargaining power and better quality of institutions. In models of biased enforcement, the rich are less likely to pay bribes, making bribery regressive. The OLS estimates of the effects of household income are likely to find spurious progressivity in the incidence of bribery in schools. We exploit temporary rainfall shocks to identify the ability to pay effect, while long-term rainfall differences identify the combined 'poor people' and 'poor area' effects. The IV estimates show that the poor are more likely to pay bribes, and the amount paid does not depend on household income. The evidence rejects the ability to pay and related models based on unbiased enforcement, and is consistent with the "refusal to pay model" of bargaining power where the rich decline to pay bribes. "Free schooling" is free only for the rich, and corruption makes the playing field skewed against the poor.

Key Words: Corruption, Bribes, Schools, Refusal to pay model, deterrence to bribe demand model, Inequality, Income Effect, Bargaining Power, Regressive Effects, Educational Mobility

JEL Codes: O15, O12, K42, I2

\footnotetext{
${ }^{1}$ Some of the materials in this paper were circulated earlier under the title "Admission is Free only if Your Dad is Rich! Distributional Effects of Corruption in Developing Countries.". The main theoretical and empirical results in this version are new, and this version supersedes the earlier version. We are grateful to Matthew Lindquist, Dilip Mookherjee, Hillary Hoynes, Jeffrey Wooldridge, Larry Katz, Rajeev Dehejia, Reshad Ahsan, Arpita Chatterjee, Arif Mamun, Ali Protik, Paul Carrillo, Virginia Robano, Atonu Rabbani, Sultan Hafeez Rahman, Rafiqul Hassan, Niaz Asadullah, Zhaoyang Hou, and seminar participants at NEUDC 2013, AEA 2013, Monash University, and BIGD inaugural annual lecture at BRAC University for helpful discussions and/or comments on earlier drafts. We thank Transparency International Bangladesh and Iftekhrauzzaman for access to the NHSC (2010) data used in this study. The standard disclaimer applies.
} 


\section{Introduction}

A large number of developing countries over the last few decades invested heavily on policies such as free universal primary and secondary schooling, stipends for girls, free books, and midday meals. The basic assumption is that such policies would lessen the burden on poor families for educating their children, and thus help reduce educational inequality and improve economic mobility. The evidence, however, shows that inequality has increased in many developing countries and educational mobility has not improved (World Development Report (2006), Hertz et. al. (2007), Emran and Shilpi (2015)).

The goal of this paper is to understand whether corruption in schools constitutes part of the explanation for the lack of improvements in educational mobility despite public policies aimed at improving access of children from disadvantaged socioeconomic background. Corruption is endemic in developing countries including in schools (Transparency International, 2013). In Bangladesh about half of the households reported paying some form of bribe for children's education (Transparency International Bangladesh, 2010). Evidence from a seven country study in Africa by World Bank shows that 44 percent of parents had to pay illegal fees to send their children to school (World Bank (2010)). ${ }^{2}$ Our focus is on the following question: who are the unfortunate half that end up paying bribes for their children's schooling? A canonical ability to pay model provides us with a sharp answer: the richer households are more likely to pay bribes, and they also pay more among the subset of bribe payers. If the ability to pay model is a valid description of the bribery in schools, then corruption helps reduce educational inequality: only the rich pay for their children's schooling. ${ }^{3}$ The available empirical evidence, in contrast, is conflicting: some showing that corruption is regressive and others providing evidence that is consistent with the incidence of corruption being progressive (see the discussion in section (2) below). Almost all of the existing evidence on the distributional effects of corruption is, however, based on OLS regressions, and does not address possible omitted variables bias due to genetic

\footnotetext{
${ }^{2}$ The countries in the study are: Ghana, Madagascar, Morocco, Niger, Senegal, Sierra Leone and Uganda. According to a New York Times report, bribery is rife not only in school admissions in China, even the front row seats in the classroom are up for sale;'A Chinese Education, for a Price", New York Times, November $21,2012$.

${ }^{3}$ The conclusion that the rich (household with higher ability to pay) are more likely to pay bribe and pay larger amount also arises in models where bureaucrat uses a screening device such as red tape to reveal the ability to pay in a separating equilibrium. In these models, it is not possible for the high income households to pay less bribes, if the bureaucrat is maximizing her income. Please see the discussion below on Banerjee (1997) and Banerjee et. al., (2009).
} 
correlations in ability and preference.

We make contributions to this literature both theoretically and empirically. The ability to pay and related screening models rely on an important assumption that law enforcement is impersonal and unbiased and thus a household's socio-economic status is irrelevant for anticorruption enforcement. We develop two models where the legal and enforcement system is not impersonal or unbiased, but works in favor of the rich to reflect the fact that higher permanent income (wealth) confers significant social and political influence in a developing country. The higher bargaining power of the richer households may thus allow them to avoid paying bribes altogether, making bribery regressive. The bargaining power that derives from higher permanent income of a household is modeled as a higher probability of punishment faced by the official when asking for bribes.

The models differ in terms of the information set of the official. In the first model, the standard (but heroic) assumption that the official observes all of the relevant household characteristics to extract full surplus is abandoned, but the information set is still rich enough so that the official observes income at the household level. The official infers the bargaining power from the observed income at the household level, and the bargaining power of a household works primarily as a deterrent against demand for bribes; the the richer households are less likely to face such demand for (and pay) bribes. In the second model, the information set is more limited and the official does not have income information to discriminate among households and demands the same amount of bribe from everyone. A household with high bargaining power can refuse to pay and still get the child admitted into the school. The bargaining power of richer households thus leads to refusal to pay bribes in this limited information model (henceforth called 'refusal to pay model'), and delivers the prediction that propensity to pay bribes is a negative function of household income, but among those who pay, the amount of bribe does not vary with household income. The distinguishing feature of the "bargaining power as deterrence" is that, among the households paying bribes, the amount paid increases with a household's income, in contrast to the 'refusal to pay model' where the amount paid does not vary with household income. The theoretical analysis in this paper thus yields contrasting predictions regarding the effects of household income on bribery at the extensive and intensive margins.

We develop and implement the following empirical methodology to understand the roles of 
ability to pay, bargaining power, institutional quality, and the information set of corrupt official in determining the distributional effects of corruption in schools. Our empirical strategy relies on the observation that rainfall is an important exogenous determinant of rural income, but shortterm rainfall shocks and long-term average rainfall variations across villages contain different identifying information. To test the ability to pay model, we focus on the effects of transitory rainfall shocks to income. If ability to pay is the primary mechanism at work, then positive transitory shocks to income would increase both the probability that a household pays bribes and the amount paid. This is a credible test, because a transitory rainfall shock is unlikely to have any significant correlation with the genetic components of preference and ability, or with a household's bargaining power and the enforcement regime in a village because they are determined by permanent income. ${ }^{4}$

To estimate the effects of poverty on propensity to pay bribes and the amount paid, we exploit the variation in long-run average rainfall across villages, and its interactions with exogenous household characteristics. Again, the validity of the identification relies on the observation that there is no credible empirical evidence that shows that the nature of genetic transmission of ability and preference depends on long-term rainfall in a region or a country. It is important to emphasize that we are not estimating the effects of permanent income in the standard sense, because variation in long-term average rainfall across villages is useful for identifying the combined "poor people" and "poor area" effects which is the focus of this paper. It captures the poor people effect because it affects permanent income, for example, through agricultural productivity, crop choices, and cropping intensity. Part of the "poor people" effect may also be due to endogenous preference and ability formation, shaped by poverty as emphasized in the recent literature (Corbin and Heckman (2016), Currie and Almond (2011), Mullainathan and Shafir (2013)). The long-term rainfall differences capture the "poor area" effect because of the quality of institutions including law enforcement, as they can affect the reach of formal legal apparatus, and may have shaped the informal (relational) arrangements in a village. ${ }^{5}$ The poor may be dou-

\footnotetext{
${ }^{4}$ We discuss later that our identification scheme is not compromised by the recent evidence showing a negative effect of transitory rainfall shock at the time when a child is in utero on her/his cognitive ability.

${ }^{5}$ This is important for the interpretation and credibility of the IV estimates. The exclusion restrictions we impose relates to only the genetic components of preference and ability heterogeneity; all other mechanisms are part of the causal effect of being "poor" and "living in a poor village", the focus of the analysis.
} 
bly vulnerable: they have lower bargaining power, and they also face weak enforcement against corruption. The upshot of the above discussion is that the effects of poverty on bargaining power of a household is an amalgam of different mechanisms, and we provide suggestive evidence that the estimated effects are primarily driven by a "pure bargaining power" effect that captures the notion that the poor are unable to inflict any costs on an official if they ask for bribes (or do not have outside option in terms of access to high cost private schools). We do not find any evidence that endogeneous ability and preference aspects are important.

The empirical evidence reported in this paper suggests that bribe taking by officials in schools affects the poor households disproportionately; poor parents are more likely to pay bribes for education of their children, and among the bribe payers, the poor pay as much as the rich. The results reject the unbiased enforcement models including the ability to pay model. The evidence that the amount paid by a household does not depend on its income rejects the deterrence version of the bargaining power model, but supports the refusal to pay version. ${ }^{6}$

The evidence and the analysis presented in this paper has important policy implications: free schooling in the presence of corruption results in a perverse outcome: 'free' schooling is free only for the richer households as they are not likely to pay bribes, while the poor still pay for their children's schooling. Without fundamental reform to improve law enforcement, free schooling and similar policies are not likely to be effective in reducing educational inequality.

Rest of the paper is organized as follows. Section (2) discusses the related literature and thus help put the contributions of this paper in perspective. The next section develops testable predictions from three models of bribe taking by school officials based on alternative assumptions regarding the nature of enforcement regime and information set of the official. The empirical strategy to address the potential biases from household heterogeneity is discussed in section (4). The next section (section (5)) provides a discussion of the data sources and variables. Section (6), arranged in a number of subsections, report the estimates from alternative econometric approaches. The OLS results are reported in subsection (6.1), the results on ability to pay effect using transitory rainfall shocks are discussed in subsection (6.2), and the corresponding results

\footnotetext{
${ }^{6}$ The analysis is also useful in sorting out the conflicting evidence in existing literature. The OLS estimates that find bribes to be regressive are likely to lead to correct conclusions, although the degree of regressivity is underestimated. However, the OLS estimates that show progressive effects may be largely driven by unobserved heterogeneity.
} 
for the bargaining models based on long-term rainfall variation are in subsection (6.3). Section (7) provides a discussion on the interpretation of the instrumental variables estimates. The paper concludes with a summary of the results and their implications for the broader debate about the role of public schooling and anti-corruption measures to address inequality in educational opportunities.

\section{(2) Related Literature}

The economics literature on corruption is substantial and has been the focus of innovative research in the last two decades. For recent surveys of the literature, see, for example, Olken and Pande (2011), Banerjee et al. (2012), Rose-Ackerman (2010), Bardhan (1997). ${ }^{7}$ The literature has, for good reasons, focused on the measurement of corruption, its effects on efficiency, and on policies to combat corruption in different contexts. For recent contributions on measurement, see, for example, Fisman (2001), Reinikka and Svensson (2004), Olken (2009), Olken and Barron (2009) and Banerjee and Pande (2009), Hsieh and Moretti (2006), Besley et al. (2011), Niehaus and Sukhtankar (2010); for contributions on costs of corruption, see, among others, Svensson (2003), Fisman and Svensson (2007), Bertrand et al. (2007), Ferraz, Finan, and Moreira (2012), Sequeira and Djankov (2010), Olken (2006, 2007, 2009), and on policies to combat corruption, see, for example, Di Tella and Schargrodsky (2004), Niehaus and Sukhtankar (2010), Olken (2007), Bjorkman and Svensson (2010), Banerjee et al. (2012), Kahn et al (2009).

The literature on the effects of corruption on households is, however, limited. The available evidence on the heterogeneity in the burden of corruption on households leads to conflicting conclusions. Kauffman et al. (1998), and Kauffman et al. (2005) reported bribes to be regressive at the intensive margin as the poor pay a higher share of their income as bribes. On the other hand, Hunt (2010) reports evidence suggesting that corruption in health care in Uganda is progressive both at the intensive and extensive margins. Hunt and Laszlo (2012) find that bribery is, in general, not regressive in Uganda and Peru. They point out that rich households use more types of public services, and thus are more likely to face bribe demand in Uganda and Peru (Mocan (2008) also makes a similar observation). Our analysis differs from theirs in an important way, because we focus on the distributional effects of bribes when both rich and poor

\footnotetext{
${ }^{7}$ The early contributions to corruption literature include Rose-Ackerman (1978), Klitgaard (1988), Shleifer and Vishny (1993).
} 
try to access the same public service: free public schooling. Thus our results cannot be due to the mechanism emphasized by Mocan (2008) and Hunt (2010). The existing studies on the relationship between household income and the propensity to pay bribes and the bribe amount paid rely on OLS regressions, and do not analyze the biases due to unobserved heterogeneity and measurement errors. Hunt and Laszlo (2012) take a step forward and correct for the biases due to measurement error in household expenditure by using household wealth indicators as instruments. To the best of our knowledge, we provide the first evidence on distributional effects of bribery in schools that deals with both measurement error and unobserved heterogeneity and discriminates among ability to pay, refusal to pay, and deterrence models of bargaining power. There is no work that deals with the central issue of our analysis: the implications of biased enforcement for incidence of corruption.

Although the potential role of relative bargaining power of briber and bribee is well-recognized in the policy analysis of corruption (see, for example, Rose-Ackerman (1996)), formal theoretical and empirical analysis has been scant. In an important and widely cited paper on misgovernance, Banerjee (1997) develops a model where a bureaucrat uses red tape to screen the ability to pay. If the bureaucrat is able to distinguish the ability to pay in a separating equilibrium, we should observe rich households paying more bribes more frequently; thus delivering conclusions similar to the canonical ability to pay model. Please see below for a more extended discussion on this point.

In an interesting paper on corruption faced by firms, Svensson (2003) develops a "refusal to pay model" where sectors differ in terms of sunk costs, and a firm's power to say no when faced with a bribe demand depends on the sunk costs (costs of exit) in the sector it operates in. The source of heterogeneity in power is thus not biased enforcement regime as is the case in our analysis. The empirical analysis of Svensson (2003), using data from Uganda, carefully tackles the identification issues, and finds that bribe amount paid by firms increases with its profit ("ability to pay"). In the context of our application, higher "profit" is similar to higher returns to education for a household, but unlike profit of a firm, it does not increase the ability to pay of poor parents. Hunt (2007) shows that victims of misfortune are more likely to pay bribes for public services, especially for police and judiciary services. The explanation for the increased corruption following a negative shock is partly based on bargaining power, but no formal model is 
offered. A negative shock increases the reliance on public services, and also lowers the bargaining power of a victim; a household, when falls victim to misfortune, is "desperate, vulnerable, or demanding services particularly prone to corruption". Our focus is different, on the role of the bargaining power that derives from higher permanent income of a household, and of the information set of the official.

\section{(3) Models of Bribery in Schools}

We develop alternative models of bribery for admission into school under different assumptions about the nature of enforcement regime and the information set of the official.

\section{The Basic Set-Up}

The official has two sources of income: salary $w$ received from employment in public schools, and bribes for admitting students to school. The households in village $j$ are heterogenous in terms of their economic status as measured by income $y_{i}$ and bargaining power $\mu_{i}$ where $i$ is the household index. The probability of punishment for taking bribes from household $i$ is $\delta_{j}\left(\mu_{i}\right)$, and we assume that the probability is increasing in the bargaining power of the household. The village index $j$ captures the notion that enforcement quality may differ across villages. The bargaining power of household $i$ depends on income and also a set of factors uncorrelated with income $\psi_{i}$, i.e., $\mu_{i}=\mu\left(y_{i}, \psi_{i}\right){ }^{8} \mu_{i}$ is increasing in both its arguments. The assumption that bargaining power $\mu_{i}$ is a positive function of household income captures the idea that the rich in a village have better bargaining power, given an enforcement regime $\delta_{j}($.$) . The functions \delta_{j}($. and $\mu($.$) are common knowledge. If caught and convicted of corruption, the school official loses$ her job, thus the payoff is zero in this case.

Income of household $i$ is a function of its resource endowment $E_{i}$ and ability of parents $A_{i}^{f}$. The households also vary in terms of their moral costs of corruption (measured in terms of utility loss) $M_{i}^{f} \in\left[M_{L}, M_{H}\right]$.

The income function is:

$$
y_{i}=y\left(E_{i}, A_{i}^{f}, M_{i}^{f}\right) \text { with } \frac{\partial y(.)}{\partial E_{i}}>0 ; \frac{\partial y(.)}{\partial A_{i}^{f}}>0 ; \frac{\partial y(.)}{\partial M_{i}^{f}}<0
$$

\footnotetext{
${ }^{8}$ Since the focus of our analysis is on household income, for most of what follows in this section, we will ignore $\psi_{i}$.
} 
So household income is increasing in its endowment and parental ability, but is a negative function of his moral cost $M_{i}^{f}$. A household with low moral cost can profit from corrupt deals and activities, for example, by getting a contract through bribing. For simplicity, $y_{i}$ is assumed to be discrete and households are ordered according to income as $y_{0}<y_{1}<\ldots<\bar{y}$. Each household has one school aged child. The quality of education received by a student $i$ is $q\left(A_{i}\right)$ where $A_{i} \in\left[A_{L}, A_{H}\right]$ is the ability of the child. The human capital function $q\left(A_{i}\right)$ is strictly increasing and concave in ability.

In addition to possible bribes for schooling, a household spends its income on a consumption good $c$. The utility function takes the following form:

$$
V_{i}=R_{q}^{i} q\left(A_{i}\right)+u\left(c_{i}-B_{i}\right)-M_{i}^{f}
$$

where $u($.$) is assumed to be increasing and strictly concave, R_{q}^{i}$ is the returns to education, and $B_{i} \geq 0$ is the amount of bribe. Admission into school ensures human capital $q\left(A_{i}\right)$, and the return to human capital may depend on the family connection, with rich expected to get higher returns given their network in the labor market. However, we will ignore the heterogeneity in returns, and focus on the implications of ability to pay, because the higher expected returns for rich will only strengthen the conclusions below. We thus set $R_{q}^{i}=1$ for all households.

\section{(3.1) A Model of Bribe Determination When Official Has Perfect Information and the Probability of Punishment Does Not Vary Across Households}

We first consider a set-up where legal and enforcement systems are impersonal, and the common probability of punishment faced by the corrupt official across different households is $\tilde{\delta}$. All the existing analysis we are aware of rely on the assumption of unbiased enforcement regime. We also assume that the school official observes income, and the type of a household in terms of ability and moral preference, i.e, the information set of the official is $\Omega=\left(y, A^{f}, A, M^{f}, \tilde{\delta}\right){ }^{9}$ The school official decides whether to ask for bribes from household $i$ given the information set. If s/he decides to ask for a bribe, the official makes a take-it-or-leave-it offer to the parents. The parents decide whether to accept the bribe demand. Then the official decides whether to admit

\footnotetext{
${ }^{9}$ This information assumption is common in many models where the official is able to extract the full surplus from the household.
} 
the child into the school.

Consider a household's decision regarding whether to pay bribe or not for school admission when the official makes a take-it-or-leave-it bribe demand. Given that the household cannot influence the probability of punishment, it is optimal for a household to pay bribe to get admission for its child into the school if the bribe demand $B_{i}$ satisfies the following:

$$
q\left(A_{i}\right)+u\left(y_{i}-B_{i}\right)-M_{i}^{f} \geqq u\left(y_{i}\right)
$$

The main results that follow from the ability to pay model are summarized in proposition (1) below.

\section{Proposition 1}

Assume that the admission official has full information and makes a take-it-or-leave-it bribe demand. In this case the participation constraint (3) binds for each household that sends a child to school.

(1.a) Bribery is progressive at the extensive margin in the sense that there exists a threshold income $\tilde{y}$ such that a household with income $y_{i}<\tilde{y}\left(A_{H}, M_{L}\right)$ is not asked for any bribe for admission.

(1.b) There exists a threshold income $y^{L}\left(A_{H}, M_{L}\right)$ below which a household is unwilling to pay a positive (however small) bribe for admission.

(1.c) Among the households with a child in school, the bribe amount is a positive function of income if the household utility function is strictly concave. In other words, bribe is 'weakly progressive' at the intensive margin.

(1.d) Bribes are progressive at the intensive margin (i.e., the bribe as a share of income increases with the level of income) only if the utility function exhibits strong enough concavity.

\section{Proof:}

Omitted. See the online appendix.

\section{Discussion}

Variants of propositions (1.a)-(1.c) have been discussed in the literature before, but proposition (1.d) is new, to the best of our knowledge. Proposition (1.d) shows that even with perfect 
information, the maximum bribe an official can extract is not progressive in the standard sense if the curvature of the utility function is not strong enough. With an isoelastic utility function, it can be shown that the bribes are progressive in the standard sense only if the utility function has more curvature than a log function (see the online appendix). ${ }^{10}$

Although the predictions that the rich are more likely to pay bribes, and pay higher amount conditional on paying are derived in the context of a simple stylized model above, similar conclusions arise in other models which share the unbiased enforcement assumption. It is instructive to consider the rich and versatile model developed by Banerjee (1997) and extended in Banerjee et al. (2009). They consider a model where corruption is the result of misaligned incentives between the bureaucrat and the government, and many different types of corruption can be considered within a common framework. Although their focus is on allocational inefficiency and red tape, the model can be used to understand who has to pay bribes and how much. ${ }^{11}$ The bureaucrat can use costly screening (testing) to find out the types of the agents who are differentiated by ability to pay and private benefit. The private benefit in their model corresponds to $R_{q}^{i} q\left(A_{i}\right)$ in equation (2) above, and ability to pay to $y_{i}$ in our set-up. If we assume that returns in the labor market are higher for the rich households, then both private benefit and ability to pay are higher for the richer households. The rich in our case correspond to the low type in their model, if the goal of the free primary schooling is to provide education to the poorest. The price set by government is zero (free schooling). Then it is easy to see that an income maximizing official will use costly screening only if she can charge higher for the children of rich parents for admission. Income maximization also implies that if there is limited number of slots available, they will screen in the children from rich families. ${ }^{12}$ In fact, it is impossible to have the opposite conclusion that the poor are more likely to pay bribes in any model that is built on the following widely used set of assumptions: (1) bureaucrat maximizes income, (2) the high type (poor in our case, assuming social returns are higher) has less ability to pay, (3) high type assigns higher

\footnotetext{
${ }^{10}$ This result is simple, but important, because most of the literature on the distributional burden of corruption uses the standard notion of progressivity from the tax literature, and the conditions required for such progressivity in the context of bribery is in general not adequately appreciated.

${ }^{11}$ However, a caveat is in order here, as it is likely that the authors would have built a different model if the focus were on the effects of corruption on inequality.

${ }^{12}$ The assumption of limited slots may not be appropriate in our context, as the rural schools never decline someone because of congestion in the classroom. The fact that half of the children who are admitted into school do not pay bribes for admission also contradicts the limited slots assumption.
} 
private value, (4) the anti corruption enforcement does not depend on household characteristics. The intuition is as follows. Assume that the school official charges $B_{p}$ and $B_{r}$ to the poor and rich respectively, with $B_{p}>B_{r}$. Also assume that the poor are more likely to pay bribes; they are asked for bribes with a higher probability. Assume that this mechanism maximizes the bribe income of the corrupt official. The poor can pay $y_{p}$ and the rich $y_{r}$, with $y_{p}<y_{r}$. Then it is obvious that $y_{p} \geq B_{p}>B_{r}$. Clearly the school official can increase her income by charging the same bribe $B_{p}$ to the rich, and by increasing the probability of asking for bribes from rich to equal that of the poor. In other words, there is a pooling equilibrium that yields more income without incurring any costs for screening, contradicting that the official is maximizing her bribe income.

\section{Testable Prediction T.1: Ability to Pay Model}

If heterogeneity in ability to pay across households determines the incidence of corruption, then a transitory positive shock to income would increase both the propensity to pay bribes for children's schooling and the amount paid conditional on paying.

To test for the importance of the ability to pay effect, we need a source of exogenous variation in household income that is not correlated with bargaining power derived from higher permanent income (wealth). Thus a transitory income shock would be an excellent source of identifying information in this context.

\section{(3.2) Heterogeneity in Bargaining Power in a Model of Biased Enforcement}

In this section, we develop two models that abandon the assumption that the legal and enforcement regime is impersonal (the "rule of law" assumption). We emphasize that "bargaining power' is used as a portmanteau term that represents a household's economic, social and political influence and the "connections" that come with higher income and wealth in a developing country. It also represents confidence and negotiation ability that may be affected by impairment of cognitive and noncognitive abilities and endogenous preference formation because of poverty. Another important point to keep in mind is that poor are also victim of weak institutions because they live in a poor area where anti-corruption enforcement may be lax. For expositional simplicity, we assume in this section that the households do not vary in terms of ability or moral costs; the main conclusions do not depend on this simplification. 


\section{(3.2.1) A Model of Bargaining Power as a Deterrent to Bribe Demand}

This subsection is devoted to the case where the information set of the school official is not as rich as the ability to pay model, but it is assumed that the official observes household level income. The official does not have any independent information on cognitive ability or moral costs, and thus can try to infer them from the income information. Since the official observes income of a household, the estimated probability of punishment is $\hat{\delta}_{i}\left(y_{i}\right)=\delta\left(\mu\left(y_{i}\right)\right)$. Note that once the official decides to ask for bribes from a household, it is optimal to extract full surplus from the household, because the probability of getting caught and punished does not depend on the bribe size. We assume that there are lower $\left(\hat{y}_{l}\right)$ and upper $\left(\hat{y}_{h}\right)$ thresholds of income such that $\hat{\delta}\left(y_{i}\right)=0$ for $\left(y_{i} \leq \hat{y}_{l}<\bar{y}\right)$ and $\hat{\delta}\left(y_{i}\right)=1$ for $\left(y_{i} \geq \hat{y}_{h}<\bar{y}\right)$. Thus we assume that the poorest of the households have no bargaining power, while the richest ones can punish the official for bribe taking with probability 1.

It follows that there exists a threshold $y^{m}<\bar{y}$, such that the following equality holds (assuming that the official maximizes expected income):

$$
\left\{1-\hat{\delta}\left(y^{m}\right)\right\}\left[B^{*}\left(y^{m}\right)+w\right]=w
$$

where $B^{*}\left(y^{m}\right)$ is the optimal bribe function. If the bargaining power effect of income is strong enough in the sense that $\frac{d \hat{\delta}(y)}{d y}$ is greater than a positive threshold, the official does not ask for bribes from any household with income higher than $y^{m}$ defined in equation (4) (for details, see the appendix)). The model thus predicts that when the bargaining power effect of income is strong enough, among all households with child in school, only the relatively poor pay bribes, the richer households $\left(y_{i}>y^{m}\right)$ are not asked for bribes, even though they have higher ability to pay. Higher income and the resulting bargaining power thus work as deterrent. The testable predictions from the bargaining power as ex ante deterrence are summarized below. 


\section{Testable Predictions T.2: Bargaining Power as Deterrence Model}

Assume that the poorest households have no bargaining power, but bargaining power increases with income, and the richest households can punish the corrupt official with certainty. The official can observe household income. Consider the set of households with a child in school.

(TP.2) The probability that a household had to pay bribes for admission is a negative function of income if the bargaining power effect of income is strong enough,. Among those who pay bribes, the amount of bribes paid is a positive function of household income.

Proof: See the appendix.

\section{(3.2.2) A Model of Bargaining Power as Refusal to Pay Bribes}

The model developed in this subsection restricts the information set more and assumes that the school official cannot discriminate across households. The sequence of events unfolds in the following way. The official sets a bribe demand $B\left(I_{j k}\right)$ where $I_{j k}$ is the indicator observed by the official for a group $k$ in village $j$. We assume that the bribe $B($.$) is a positive function of I_{j k}$. We do not spell out a complete model of how the exact amount $B$ is determined, as it is not necessary for deriving the testable predictions. Our results are valid for any model where the official cannot bribe discriminate among households. In some cases, the information may be so coarse that the officials across villages charge effectively the same bribe rates. This can happen when bribe amount is tied to national cost of living index. ${ }^{13}$

When a household goes for admission of its child into the school, the school official demands a payment of $B\left(I_{j k}\right)$. The parents decide whether to pay or not. If they pay the bribe, the child is admitted. If they decline, then the parents can deploy their bargaining power, for example, a call to the official from the local political leader or from the office of education minister in capital city (revealing higher bargaining power). The official estimates the probability that she will be punished for insisting on bribes and not admitting the child, following the revelation of household's bargaining power. If the bargaining power is strong enough then the school official admits the child even without the bribe. To capture the notion that higher income bestows higher bargaining power, we assume that the estimated probability of punishment $\hat{\delta}_{i}$ is

\footnotetext{
${ }^{13}$ In fact, there is evidence that bribe rates for some public services in some countries look like market price, because the same bribe is demanded irrespective of socio-economic background of a briber (Rose-Ackerman (2010, 1978).
} 
a positive function of a household's income (or wealth), i.e., $\hat{\delta}_{i}=\delta\left(y_{i}\right)$ and $\frac{d \hat{\delta}_{i}(.)}{d y_{i}}>0$. Note that the probability of punishment estimated by the official is a positive function of household income in the data even though the official does not know household income, as long as the bargaining power revealed by a household's refusal to pay is correlated with household income.

The above model implies that the households with income higher than a threshold refuse to pay the bribe, but still get their children admitted into the school. The threshold household income level (denoted as $y_{j k}^{r}<\bar{y}$ ) above which a household gets the child admitted after refusing to pay bribes is determined by the following (assuming that the official maximizes expected income):

$$
\left\{1-\hat{\delta}\left(y_{j k}^{r}\right)\right\}\left[B\left(I_{j k}\right)+w\right]=w
$$

Since the official cannot tailor the bribe to an individual household, the model predicts that bribes for school admission are regressive both at the extensive and intensive margins: the rich are less likely to pay bribes, and the poor pay more as a proportion of income among the households that pay bribes for children's admission. An important testable implication is that the amount of bribe paid does not depend on household income. The above discussion yields the following testable predictions about the distributional effects of bribes for school admission which we take to data in a later section of the paper.

\section{Testable Predictions T.3: Refusal to Pay Model}

Assume that the official does not observe individual household income, but observes wealth indicators at the group level. The household can deploy its bargaining power once the bribe demand is made. The bargaining power is a positive function of a household's income. A higher bargaining power leads to higher probability of punishment for the corrupt official. Consider the set of households with a child in school.

(TP.3) Then a higher household income reduces the probability that it had to pay bribes for child's admission into school, but, among those who pay, the amount paid does not depend on a household's income. 


\section{(4) Empirical Issues and Strategy}

Our focus is on household income as an indicator of a household's economic status. An alternative, widely used in the existing literature, is household consumption expenditure. The choice of consumption expenditure by many researchers is motivated by the observation that it is less prone to measurement error compared to income. However, an important problem with consumption expenditure as an indicator of economic status in an analysis of bribery by households is that consumption and bribe payments are simultaneously determined, given income (see equations (1) and (3) above). Simultaneity bias is thus a serious problem in addition to omitted heterogeneity and measurement error in the case of household consumption expenditure. We thus prefer income as the indicator of economic status of a household.

Consider the following triangular model for bribery for school admission at the extensive and intensive margins. The first two equations refer to propensity to pay bribes and amount paid conditional on paying, respectively. The third is a selection equation that captures heterogeneity in household income.

$$
\begin{aligned}
P\left(D_{i j}\right. & =1)=\beta_{0}+\beta_{1} \delta_{j}+\beta_{2} y_{i j}+\pi X_{i j}+\beta_{A} A_{i j}+\beta_{M} M_{i j}^{f}+\beta_{p} \mu_{i j}+\zeta_{i j} \\
B_{i j} & =\theta_{0}+\theta_{1} \delta_{j}+\theta_{2} y_{i j}+\Gamma X_{i j}+\theta_{3} I_{j k}+\theta_{A} A_{i j}+\theta_{M} M_{i j}^{f}+\nu_{i j} \\
y_{i j} & =\alpha_{0}+\Pi X_{i j}+\alpha_{A} A_{i j}^{f}+\alpha_{M} M_{i j}^{f}+\varsigma_{i j}
\end{aligned}
$$

where $i$ is the household index, and $j$ is the village index, $D_{i j}$ is a binary variable that takes on the value of 1 when the household had to pay bribes for educational services, $B_{i j}$ is the amount paid, $\delta_{j}$ is a measure of enforcement in village $j, y_{i j}$ is the income of household $i$ in village $j, X_{i j}$ is a vector of control variables, $\mu_{i j}$ is household's bargaining power, $I_{j k}$ is the indicator used by the official under the refusal to pay model, and $\zeta_{i j}$ and $\nu_{i j}$ are the error terms. It is important to emphasize here that the bargaining power effect in the above empirical model $\left(\beta_{p}\right)$ does not include the enforcement effect or the possible endogenous effects of poverty through ability and preference formation, as we include controls for them. Below we develop the empirical model to include such effects. To avoid confusions, we call the effect represented by $\left(\beta_{p}\right)$ as the "pure bargaining power effect".

We expect that $\beta_{p}, \alpha_{M}, \beta_{M}, \theta_{M}<0$. Since better enforcement in a village reduces the scope 
for corruption, we expect $\beta_{1}, \theta_{1}<0$. As discussed before, $\theta_{2}=0$ if refusal to pay model holds in the data. Also note that the household bargaining power does not affect the amount paid, a prediction shared by all three models discussed in section (3) above. ${ }^{14}$ The ability to pay model implies that $\beta_{2}>0$ and $\theta_{2}>0$.

The empirical model in equations (6)-(8) makes precise the idea of higher ability to pay of a high income household represented by the parameters $\beta_{2}$ and $\theta_{2}$. Part of the difficulty in estimating the ability to pay effect arises from the fact that the household income also captures the effects of household bargaining power and village enforcement regime. As discussed before, the enforcement regime in a village is likely to depend on its level of development, and the probability is higher that a high income household chooses to live in a village with better law enforcement due to spatial sorting based on income and amenities. We can thus decompose the enforcement into two components, $\delta_{j}=\lambda_{1} y_{i j}+\lambda_{2} \delta_{j}^{-y}$, i.e., a part of the enforcement is correlated with household income, but it is also determined by a vector of other factors uncorrelated with income (denoted as $\delta_{j}^{-y}$ ). Similarly, it is useful to decompose the bargaining power of a household into two components: $\mu_{i j}=\omega_{1} y_{i j}+\omega_{2} \mu_{i j}^{-y}$, a component correlated with household income and a second part orthogonal to income (denoted as $\mu_{i j}^{-y}$ ). Since poverty can affect the cognitive and noncognitive abilities and shape preference, we decompose the ability and moral costs into genetic and non-genetic components : $A_{i j}=\tau_{0} A_{i j}^{f}+\tau_{1} y_{i j}$ and $M_{i j}^{f}=\rho_{0} M_{i j}^{g f}+\rho_{1} y_{i j} \cdot{ }^{15}$

Note that when cognitive and noncognitive abilities of a child is affected adversely by poverty $\left(\tau_{1}>0\right)$, the parents may expect low returns to investing in her education, suggesting that they will be less willing to pay bribes. In contrast, when the main impact of low ability is low confidence and negotiation ability, then we expect that the poor households will be more likely to pay bribes, ceteris paribus. Under the assumption that moral probity is a normal good, we expect $\rho_{1} \geq 0$. To avoid confusions, we reiterate that this endogeneous effect of income on preference is different from the effect of moral costs on the income of a household captured by $\alpha_{M}<0$ in equation (8) above.

\footnotetext{
${ }^{14}$ This captures the idea that if you are not able to refuse a demand for bribes, it is likely that you have little bargaining power to resist the official from extracting the surplus.

${ }^{15} \mathrm{~A}$ large literature on intergenerational mobility shows that parent's and children's income, education, and occupation are positively correlated. On developing countries, see Hertz et al. (2007), and Emran and Shilpi (2011,2015), among others.
} 
The empirical model can now be rewritten as below:

$$
\begin{aligned}
P\left(D_{i j}\right. & =1)=\beta_{0}+\beta_{T} y_{i j}+\pi X_{i j}+\varepsilon_{i j} \\
B_{i j} & =\theta_{0}+\theta_{T} y_{i j}+\Gamma X_{i j}+\kappa_{i j} \\
y_{i j} & =\psi_{0}+\Pi_{1} X_{i j}+v_{i j}
\end{aligned}
$$

where we have:

$$
\begin{gathered}
\beta_{T}=\beta_{2}+\beta_{1} \lambda_{1}+\beta_{p} \omega_{1}+\beta_{A} \tau_{1}+\beta_{M} \rho_{1} \\
\theta_{T}=\theta_{2}+\theta_{1} \lambda_{1}+\theta_{A} \tau_{1}+\theta_{M} \rho_{1}
\end{gathered}
$$

and the error terms are:

$$
\begin{aligned}
& \varepsilon_{i j}=\left(\beta_{A} \tau_{0}\right) A_{i j}^{f}+\left(\beta_{M} \rho_{0}\right) M_{i j}^{g f}+\left(\beta_{p} \omega_{2}\right) \mu_{i j}^{-y}+\left(\beta_{1} \lambda_{2}\right) \delta_{j}^{-y}+\zeta_{i j} \\
& \kappa_{i j}=\theta_{3} I_{j k}+\left(\tau_{0} \theta_{A}\right) A_{i j}^{f}+\left(\theta_{M} \rho_{0}\right) M_{i j}^{g f}+\left(\theta_{1} \lambda_{2}\right) \delta_{j}^{-y}+\nu_{i j} ; \quad v_{i j}=\psi_{A} A_{i j}^{f}+\psi_{M} M_{i j}^{g f}+\varsigma_{i j}
\end{aligned}
$$

and the parameters in equation (11) are the rescaled parameters from equation (8), for example, $\psi_{0}=\frac{\alpha_{0}}{1-\alpha_{M} \rho_{1}}$. Note that $1-\alpha_{M} \rho_{1}>0$ because $\alpha_{M}<0$, and $\rho_{1} \geq 0$. The empirical model above in equations (9)-(11) is useful in developing a credible empirical strategy to estimate the ability to pay effect and in discriminating among alternative models of bribery in school developed in section (3) above. The first important point often not adequately appreciated is that the effect of income on propensity to pay bribes $\left(\beta_{T}\right)$ may capture a number of things including ability to pay $\left(\beta_{2} \geq 0\right)$, a pure bargaining power effect $\left(\beta_{p} \omega_{1}<0\right)$ and a quality of institutions effect $\left(\beta_{1} \lambda_{1}<0\right)$. Thus the common practice of interpreting the coefficient of household income in a propensity to pay regression as ability to pay effect is likely to be misleading. The second important point not adequately recognized in the current literature is that the nature of omitted variables bias depends on the information set of the official. We provide a fuller discussion below.

\section{Information Set of the Official and Omitted Variables Bias}

The theoretical analysis and empirical models set-up above point out two possible sources of omitted variables bias: heterogeneity in ability and moral probity across households due to genetic transmissions across generations. Consider first the standard ability to pay model where these are observed by the official (or has information to estimate them reasonably well). In 
this case, both the propensity to pay bribes and the amount paid conditional on paying are susceptible to bias due to omitted heterogeneity in ability and moral probity, as the official uses this information in her decision. In this case, the OLS estimate is clearly biased towards finding a positive coefficient on household income because it is difficult to control for ability and moral cost heterogeneity. This can be illustrated by the classic ability bias applied to the present context. The demand for children's education may be higher in richer (high ability) households because of higher cognitive ability of children transmitted genetically from parents to children. Moral deficiency may help accumulate wealth through corruption, and they may also be less likely to object to paying bribes for schooling. The resulting bias in the estimated effect of household income on probability of paying bribes is given by (denoting the variance of the genetic component of moral cost by $\sigma_{M g}^{2}$ ) :

$$
\operatorname{Cov}\left(\varepsilon_{i j}, v_{i j}\right)=\frac{\beta_{A} \tau_{0} \alpha_{A}}{1-\alpha_{M} \rho_{1}} \operatorname{Cov}\left(A_{i j}, A_{i j}^{f}\right)+\frac{\alpha_{M} \beta_{M} \rho_{0}}{1-\alpha_{M} \rho_{1}} \sigma_{M g}^{2}>0
$$

The last inequality reflects that fact that we expect $\operatorname{Cov}\left(A_{i j}, A_{i j}^{f}\right)>0$, and $\alpha_{A}, \beta_{A}, \tau_{0}, \rho_{0}, \rho_{1}>$ $0, \alpha_{M}, \beta_{M}<0 .{ }^{16}$ Thus the source of positive bias in the OLS estimates of the income effects is the genetic correlations in ability and preference regarding corruption (moral costs). Evidence from OLS regressions showing that the rich are more likely to pay bribes is thus should be treated with caution. Note that the endogenous response in moral preference to income captured by $\rho_{1}>0$ gives rise to a multiplier effect in the bias due to omitted genetic ability and preference correlation.

In the deterrence model of bargaining power, the official observes household income and estimates the ability (and willingness) to pay based on this information. If the official is aware that a higher income household is likely to value children's education more because of the expected higher genetic endowment of ability as discussed above, then the official's optimal decision would reflect this positive correlation between income and ability, and the OLS estimate of the effects of income on propensity to pay bribes and the the amount paid will be biased upward. However, we would expect the bias to be less pronounced, in general, when compared

\footnotetext{
${ }^{16}$ The available evidence from economics and behavioral genetics shows that the correlation in cognitive ability of parents and children is about 0.30-0.40 providing a firm basis for $\operatorname{Cov}\left(A_{i}, A_{i}^{f}\right)>0$. See Black et al. (2009), and Plomin and Spinath (2004).
} 
to the bias implied by the ability to pay model where the official observes cognitive ability directly. Similar arguments hold for moral cost heterogeneity, the OLS estimates are biased if the official makes inference about moral probity from household's income information.

In the refusal to pay model, whether a household pays bribes depends on its bargaining power once a bribe demand is made. Ability heterogeneity can bias the OLS estimate of the effects of household income on propensity to pay for the following reason. How successful a parent is in deploying her bargaining power may depend on cognitive (and non-cognitive) ability, which would result in positive correlations among $\hat{\delta}, y_{i j}$ and parental unobserved ability $A_{i j}^{f}$. The available household surveys on corruption do not pay much attention to the information set of the official, and it is not possible to construct an adequate proxy for $I_{j k}$. Under the refusal to pay model, it is thus absorbed in the error term. More important is the observation that, in a refusal to pay model, the official cannot discriminate across household's economic status implying $\operatorname{Cov}\left(y_{i j}, I_{j k}\right)=0$ in a village. If an official uses village level indicators to set significantly different bribe rates across villages, the estimates of the effect of household income on the amount paid should change substantially when we include village fixed effects in OLS regression.

It is important to appreciate that the possibility of incorrectly concluding that bribes are progressive increases when we control for the heterogeneity in village enforcement regime, and this is true irrespective of the model under consideration. When a researcher uses village fixed effects in household level bribe regressions to control for "unobserved village heterogeneity", the parameter that is being estimated for propensity to pay bribes is $\left(\beta_{2}+\beta_{p} \omega_{1}+\beta_{A} \tau_{1}+\beta_{M} \rho_{1}\right)$, $\operatorname{not}\left(\beta_{2}+\beta_{p} \omega_{1}+\beta_{A} \tau_{1}+\beta_{M} \rho_{1}+\lambda_{1} \beta_{1}\right)$. It is thus easier to obtain a positive coefficient from OLS regressions with a relatively moderate amount of omitted variables bias due to genetic components of ability and moral cost, because $\lambda_{1} \beta_{1}<0$. An important implication of the above discussion is that, when one finds a negative effect of household income on the propensity to pay bribe in OLS estimates from an empirical model with village fixed effects, it is sufficient evidence for a regressive causal effect of bribes. However, the degree of regressivity is underestimated due to unobserved heterogeneity in ability and preference. 


\section{(4.1) An Instrumental Variables Approach}

\section{(4.1.1) Testing Ability to Pay: The Effects of Temporary Shocks to Household}

\section{Income}

Transitory income shocks provide a way to test the importance of ability to pay effect as captured by $\beta_{2}, \theta_{2}>0$. To disentangle the role of ability to pay, we need a source of exogeneous variation in household income that is uncorrelated a household's bargaining power or potential enforcement heterogeneity across villages. Transitory rainfall shocks provide us with such an exogeneous variation, because bargaining power and enforcement quality are determined by permanent income differences.

To the best of our knowledge, there is no evidence that short-term rainfall shock is correlated with genetic transmission of ability and preference from parents to children. There is evidence that a short term rainfall shock when a child is in utero can have negative effect on cognitive ability. This, however, does not compromise our identification strategy for the following reason. We calculate rainfall shock as the deviation of the rainfall in the immediate past year (2009) from its 10 year average (2000-2009). Thus it is not relevant for the school children who are the focus of our analysis; they are not in utero at the time of the rainfall shock. ${ }^{17}$ Note that, under the null hypothesis that ability to pay model is appropriate, $\theta_{3}=0$ and the variable $I_{j k}$ is not a component of the error term $\kappa_{i j}$ in equation (10).

We define five dummies for five quintiles of rainfall deviations. The preliminary analysis indicates that too little (lowest quintile) or too much (upper two quintiles) rainfall relative to long term trend are negatively correlated with household income. These three quintile dummies are then interacted with household head's age and religion to generate household level variations. There is substantial experimental evidence that the older people are more risk averse, which implies that a rainfall shock may have different effects depending on age of the household head. Religious minority (Hindu and Buddhist) in Bangladesh have more dense social network which may help in risk and information sharing. We control for household head's age and religion to ensure that the instruments do not pick up any direct effect of these variables on propensity

\footnotetext{
${ }^{17}$ Perhaps more important for our conclusions is the fact that lower cognitive ability due to negative rainfall shocks would imply that the demand for education is lower, and the poor households should be less likely to pay bribes, contrary to the findings reported below.
} 
to pay bribes, and on the amount paid. The estimates of the effects of household income on propensity to pay and amount paid using the rainfall shocks will be significantly positive if ability to pay is important in bribing decisions of the households.

\section{(4.1.2) Estimating the Effects of Poverty and Testing Refusal to Pay Model versus}

\section{Deterrence to Bribe Demand Model}

By design the transitory rainfall shock gets rid of the effects of permanent income and thus purges off the role played by enforcement and bargaining power effects of household income. To estimate the causal effect of permanent income, i.e., $\beta_{T}=\left(\beta_{2}+\beta_{p} \omega_{1}+\beta_{1} \lambda_{1}+\beta_{A} \tau_{1}+\beta_{M} \rho_{1}\right)$, we exploit variations in long-run rainfall in levels, as opposed to deviations from long-run trend used for rainfall shock in section (4.1.1) above. The instrument is defined as a dummy which takes the value of unity if average rainfall in an area is above 75 th percentile of rainfall for the country during last 10 years (2000-2009) and zero otherwise. This high rainfall dummy is then interacted with household head's age and religion to generate additional exogeneous variations. Economic activities in the villages in Bangladesh have historically been dominated by agriculture and determined to a large extent by rainfall variations. The long run rainfall is highly correlated with income because it affects agricultural productivity through technology adoption (green revolution), cropping intensity and crop choice. High rainfall areas are more flood prone in Bangladesh, with adverse effects on transport and communications infrastructure, which is likely to reduce income by restricting access to urban markets (Emran and Hou (2013)). We thus expect lower permanent income in high rainfall areas. Again, we use household level variations by interacting the high rainfall dummy with household head's age and religion.

The litmus test for discriminating between the deterrence vs. refusal to pay models of bargaining power is the effects of long-term rainfall induced differences in the permanent income on the amount of bribe paid conditional on paying; the effect should be positive if the deterrence model is valid, and it should be zero if the refusal to pay model is consistent with the evidence. Note that while ability and preference heterogeneity (genetic) can bias the estimated effect under both the deterrence and refusal to pay models, any potential bias arising from the unobservability of the official's information set is relevant only under the refusal to pay model where $\theta_{3}>0$. Thus, only if we are testing the null hypothesis of refusal to pay model, the source of exogeneous variation in household income should not be significantly correlated with the in- 
dicators used by the official for setting the bribes. Since we exploit household level variations by interacting rainfall with head's age and religion, it is highly unlikely that our instruments would be systematically correlated with the indicators used by corrupt officials in refusal to pay model where the official does not possess any household level information in a village. As noted earlier, we can test the importance of village level indicators in deciding the amount of bribes by comparing the estimates with and without the village fixed effect in OLS regressions. If the officials do not rely on village level indicators in deciding the bribe amount, the estimated effect of income will not change substantially when we include village fixed effects.

To ensure that the long-term rainfall based instruments do not capture any direct effect of age and religion on bribery, we include household head's age and religion as controls in all of the IV regressions. Conditional on the covariates, the exclusion restriction with regards to

the genetic components of ability and preference (for/against corruption) heterogeneity seems plausible, as we are not aware of any credible evidence that long-term rainfall differences across regions of country affect the strength of genetic transmissions independent of its effects through household's economic conditions (permanent income).

\section{Sorting Out the Mechanisms}

The effects of permanent income on propensity to pay bribes using long-term rainfall variations provides us an unbiased estimate of $\beta_{T}=\beta_{1} \lambda_{1}+\beta_{2}+\beta_{p} \omega_{1}+\beta_{A} \tau_{1}+\beta_{M} \rho_{1}$. The different components of the parameter $\beta_{T}$ refer to different mechanisms through which a household's economic status can affect its vulnerability to corruption. We take advantage of rich data on bribe payments for noneducational public services to create indicators of village level enforcement and household level moral cost heterogeneity (see the next paragraph). This allows us to make progress on understanding the role of different components by using controls for enforcement in a village and heterogeneity in moral probity across households. The estimates of the effects of household income on the propensity to pay bribes for education controlling for these measures of enforcement and moral cost heterogeneity would provide us suggestive evidence on the importance of these factors. However, it is not possible to control for ability differences across households which would have allowed us to provide an estimate of the "pure bargaining power effect" as captured by $\beta_{1} \lambda_{1}$. The reason is that the most credible indicator of ability is the education of the household head, but it is also highly correlated with a household's perma- 
nent income, making it impossible to isolate the effects. Note that the estimate of the income coefficient when controlling for indicators of moral cost and enforcement heterogeneity is approximately: $\beta_{T} \simeq \beta_{1} \lambda_{1}+\beta_{2}+\beta_{p} \omega_{1}$. However, we get a credible estimate of $\beta_{2}$ from the IV estimate using short-term rainfall shocks as discussed above. We can thus net out the effects of ability to pay mechanism, by using this estimate. This provides us a lower bound estimate of the "pure bargaining power effect" $\left(\beta_{1} \lambda_{1}<0\right)$, because $\beta_{p} \omega_{1}>0$.

The measures of village level enforcement and household level moral cost heterogeneity are constructed as follows. For moral costs, since the worry is that people with low moral costs of corruption enrich themselves through corrupt activities, we need indicators of corruption generated income (wealth). The main sources of corrupt wealth in rural Bangladesh are credit default (by bribing officials at the banks), land administration (bribing to grab others land), tax evasion, agricultural services (subsidies and government loans for agriculture). The survey used in the empirical analysis fortunately collected detailed information on household's propensity to pay bribes for a range of services required for wealth accumulation by a morally deficient household. We construct a measure of household heterogeneity in corruption for income generation and wealth accumulation by aggregating the propensity to pay bribes for these activities. As an index of village level enforcement, we calculate the propensity to pay bribes for non-educational services by all other households (i.e., we exclude the household under focus).

\section{(5) Data}

The data on corruption and bribe payments in acquiring educational services come from the National Household Survey on Corruption 2010 (NHSC, 2010) conducted by the Transparency International of Bangladesh (TIB). Using the Integrated Multipurpose Sampling (IMPS) Frame developed by the Bangladesh Bureau of Statistics as the sample frame, the survey selected 300 primary sampling units (PSUs) from 16 strata. The IMPS identified 1000 PSUs using the 2010 population census as the frame. The PSU borders are defined to be contiguous census enumeration blocks (usually about 2 blocks) and consists of 200 households. Note that with 200 households a PSU would be a small geographic unit in the context of Bangladesh where population density is very high. According to 2011 population census (preliminary report), per square kilometer population in Bangladesh is 964. The average household size in our sample is 5.84, which would imply that a PSU covers somewhat larger area than one square km. Thus 
PSU can be treated as a small village in most of the cases.

From each PSU, 20 households were selected randomly, giving us a total sample of 6,000 households. The sample used in our empirical study is however smaller (3605). Because we restrict the sample to those households who reported using educational services during the survey year to make sure that the households that face a zero probability of paying bribes for education are excluded. This reduces the sample size to 4876. Since incomes of households in metropolitan city corporations are not likely to be affected significantly by rainfall, we drop 851 households living in metropolitan areas. We also drop 257 households who reported having no school age children (age 6-20 years), 2 households that failed to report the gender of the household head, and another 161 households did not use any of the income generating non-educational public services. Our final sample thus consists of 3,605 households.

The NHSC 2010 collected detailed information on 13 different types of services usage, and corruption faced by households in obtaining those services. In the case of education, an adult member of the household was asked detailed questions about facing bribery regarding different educational services. The bribe questions were organized in four main categories: bribe payment for (i) admission into school, (ii) receiving free books, (iii) receiving scholarships, and finally (iv) implicit bribe payment in the form of paying fees or donations without receipts. Using responses to these questions, we define an overall propensity to pay bribes for education services as a dummy which takes a value of unity if household reported to pay any of these four types of explicit or implicit bribe and zero otherwise. Since paying without receipts is common in Bangladesh, and many people may not view it as paying bribes, we define an alternative propensity to pay bribe variable by excluding 'paying without receipt' as a bribe category. We also make a distinction between bribe paid for admission and all other types of bribe. Appendix Table A1 reports the summary statistics for different bribes related to education (please see online appendix). About 48 percent of the households reported to have paid bribe including payments made without receipts. Among the sub-categories, bribe for school admission is reported by 10 percent, for free books by 6 percent and for drawing scholarship money by 4 percent of the households. All together 18 percent of the households paid bribe for admission, free books and scholarships. About 40 percent of the households reported making a payment without receipts. In the empirical analysis we present results on both the overall propensity to pay bribe (including 
payment without receipts) and the sub-categories as well. As to be expected, the sample used for the analysis of the intensive margin (i.e., the amount of bribes paid) are smaller, about 1747 households, because about half of the households with children in school do not pay bribes. The amount of bribe paid includes payments made for any of the four different categories of bribe defined above. Among the households who reported positive amount of bribe payment, on average a household paid about Taka 247 during the survey year. To get a better sense of the financial burden imposed on the poor, it is instructive to look at the average bribe paid as a proportion of the household savings. The average bribes paid in schools is 9 percent of average annual household savings, while for the first and second quintile it amounts to 83 percent and 28 percent of annual household savings respectively. Bribes paid for schooling of the children can thus be a substantial burden on the poorest households.

The NHSC 2010 collected information on household size and the number of school-aged children, household head's age, gender, and religion. We use this information to define control variables for our regression analysis. The survey also collected information about household's total monthly income and expenditure. Summary statistics for all of these variables are provided in the online appendix Table $A 1$.

For the instrumental variables analysis, we need rainfall information which are not collected in the NHSC survey. The rainfall data are drawn from Bandyopadhyay and Skoufias (2012). The original data on rainfall come from the Climate Research Unit (CRU) of the University of East Anglia. The CRU reported estimated monthly rainfall for most of the world by the half degree resolution from 1902 to 2009. The CRU estimation combines weather station data with other information to arrive at the estimates. To estimate the thana level rainfall from the CRU data, Bandyopadhyay and Skoufias (2012) uses area weighted averages. ${ }^{18}$

\section{(6) Empirical Evidence}

We begin with preliminary evidence on the extent and pattern of bribery in schools. The first interesting point to note is that the average per capita income of the bribe payers (Tk. 1930 per month) is much lower compared to the average per capita income of non-payers (Tk. 2580

\footnotetext{
${ }^{18}$ For example if an Upazila/thana covers two half degree grid cells for which CRU has rainfall estimates, then upzila/thana rainfall is estimated as the average rainfall of the two grid-cells, where the weights are the proportion of the area of the upazila/thana in each grid-cell. For details, please see Bandyopadhyay and Skoufias(2012).
} 
per month). This indicates that on average the households that end up paying bribes for their children's education are relatively poor. To explore further the partial correlations in the data, we report a series of OLS regressions with alternative sets of controls.

All standard errors reported in this paper are clustered at PSU level if not reported otherwise. ${ }^{19}$ Clustering at the PSU level is motivated by two factors. First, households living in a village face similar choices in terms of school access and quality. Second, the first stage of stratified random sampling used in NHSC 2010 selected 300 PSUs from the IMPS sample frame of 1000 PSUs, as discussed above in the data section. All of the regressions also include regional dummies (six regions called 'divisions') to account for any spatial differences. ${ }^{20}$ The household level controls include household head's age, gender, a dummy for religion (=1 if muslim and zero otherwise), household size and number of school age children.

\section{(6.1) OLS Estimates}

Table 1 provides the OLS estimates of the coefficients on per capita income in the regressions of propensity to pay bribes and the amount paid as bribe. The Probit estimates are similar and omitted for brevity. The results for propensity to pay bribes for different types of schooling services are presented in panels A-D of Table 1, while panel E reports the estimates for the bribe payments. In addition to an overall indicator of bribing propensity that aggregates bribery for various educational services in panel $\mathrm{A}$, we provide estimates for three disaggregated categories in panels B-D: bribing for admission, bribe payments with receipts, and payments without receipt. For each indicator of bribery, we report estimates from 4 different specifications across columns. The simplest specification in column 1 includes only a vector of household controls such as age, gender and religion of household head, along with regional fixed effects, but no controls for moral cost or village enforcement regime are included. The OLS estimate in column 1 shows that the effects of higher household income are consistently negative for propensity to pay bribe, across three categories, and also in the aggregate. This provides suggestive evidence that the propensity to pay bribes for educational services may be lower for a higher income household.

\footnotetext{
${ }^{19} \mathrm{PSU}$ is a geographic unit approximately equal to a one square $\mathrm{Km}$ in our data set. All the conclusions in this paper remain valid if we cluster the standard errors at the Thana level which is a somewhat larger geographic unit than the PSU.

${ }^{20}$ Note that although Rangpur became the 7th division at the beginning of 2010, the NHSC 2010 data are organized based on the six divisions before 2010. The results and conclusions reported below, however, do not depend on the inclusion or exclusion of regional fixed effects.
} 
The estimated effect of household income on the amount paid as bribe is, however, positive and statistically significant at the 1 percent level. The evidence in column 1 thus seems to suggest that, among the bribe payers, the richer household pay more, implying that bribes are progressive at the intensive margin which we show later is an incorrect conclusion.

The second column adds a measure of household's corruption generated income to address the bias due to moral cost heterogeneity, and the estimate is a bit smaller in magnitude (compared to that in column 1). ${ }^{21}$ The specification in the third column of Table 1 introduces a control for differences in enforcement regimes across villages: the average propensity to pay bribes for noneducational public services in a village (excluding the household $i$ ). If the enforcement is weak in a village, the incidence of bribery will be higher, ceteris paribus. ${ }^{22}$ For all four measures of propensity to bribe, the effect of higher household income is negative, but numerically smaller in column (3) compared to the corresponding estimates in column (1), suggesting a less regressive effect, consistent with the theoretical insights and the empirical model that weak enforcement in low income villages affect the poor adversely. The estimates in column (3) of panel E suggest that the amount paid increases with income, but the numerical magnitude of the effect does not vary significantly between columns (2) and (3), and the magnitude is somewhat larger in column (1).

The last column in Table 1 reports estimates from a specification where we use village fixed effects instead of village level controls for heterogeneity in enforcement regime. The main conclusions remain intact, although the numerical magnitudes of the estimated effect are significantly smaller. It is important to emphasize that a negative coefficient on income estimated in the specification with village fixed effect in column (4) is sufficient to establish that bribes for education are regressive at the extensive margin, although OLS underestimates the degree of regressivity. The positive effects estimated for the amount paid, however, cannot be taken at face value, because it can be an artifact of omitted ability and moral cost heterogeneity due to genetic transmissions. A comparison of columns (1) and (4) for panel E shows that the estimate of the effects on

\footnotetext{
${ }^{21}$ The coefficient of the propensity to bribe for income generating activities is positive and statistically significant at the 1 percent level in all regressions for propensity to pay bribe. Note that this controls for both the genetic and nongenetic components of preference, and thus the estimates are lower bounds.

${ }^{22}$ The average propensity to pay bribe for non-educational services by other households in the village has positive and statistically significant coefficients in the regressions for payments without receipt and aggregate propensity to pay bribe.
} 
the amount paid does not change when we include village fixed effects. This implies that the amount paid does not vary across villages. Perhaps the more important implication relates to the refusal to pay model: the officials do not use village level indicators including rainfall to set the bribe amount. This is important evidence in favor of rainfall-based identification under the null hypothesis that the refusal to pay model is valid.

The evidence also suggests that the regressive effects found in some existing studies based on OLS regressions may not be widely off the mark, while the studies that find progressive effects in OLS should be interpreted with due caution.

(6.2) Ability to Pay: Instrumental Variables Estimates Using Transitory Rainfall

\section{Shocks}

The estimated effects of household income variation that arises from transitory rainfall shocks are reported in Table 2. The first four columns refer to propensity to pay bribes. Starting with the estimates for aggregate propensity (adding up admission, other payments with and without receipts) in column (1), we report estimates for three disaggregated categories of educational services in columns (2)-(4). The last column reports the estimates for the amount of bribe paid.

To ensure that the IV estimates do not suffer from weak instrument bias, we follow a procedure suggested by Rajan and Subrahmanian (2008). We first use the transitory rainfall shock based instruments to predict household income from a "zero stage" regression. Then the predicted income is used as the single instrument in a just identified model. As pointed out recently by Kolesar et al. (2014), this procedure requires that only the predicted income satisfies the exclusion restriction, which is a weaker assumption than exclusion restrictions imposed on the individual instruments separately. The first stage results for various specifications of propensity to pay equation show that the transitory rainfall shock based instruments are strong enough to identify the effects of a transitory change in household income; the Angrist-Pischke F statistic in each case is higher than the Stock-Yogo critical value of 9.08 for 10 percent maximum relative bias. When estimating the effects of household income on the amount paid conditional on paying, the power of the instruments is a bit lower but adequate in specifications with no controls for village level enforcement heterogeneity. Thus the estimates for the causal effect of household income on amount paid conditional on paying do not suffer from weak instrument bias when no controls for village enforcement is used. However, the Angrist-Pischke F statistic for 
the specification including an indicator of enforcement in the village is 7.73 , and some readers may worry that these particular estimates may not be free of weak instrument bias. We thus check estimates from alternative estimators such as Fuller LIML and CUE-GMM for the amount of bribe paid that are robust to weak instrument bias, in addition to the 2SLS estimates. As noted by Stock and Yogo (2005), if there is significant weak instrument bias, the estimates from Fuller-LIML and CUE-GMM will differ substantially from the 2SLS estimates.

The estimates from three different specifications for propensity to pay bribes point to a robust conclusion: there is no evidence of a significant effect of transitory changes in household income; none of the estimates are statistically significant at the 10 percent level across specifications and different categories of bribe payments. The IV estimate for the amount paid as bribes is reported in the 5th column in Table 2; the estimate is consistently positive, but, again, none of the estimates are significant at the 10 percent level. For the specification that includes a control for enforcement heterogeneity across villages, the Fuller-LIML and CUE-GMM estimates are very close to the 2SLS estimate, thus allaying worries about weak instrument bias (not reported in Table 2). The estimates from Fuller-LIML and CUE-GMM are omitted for the sake of brevity and are available from the authors. The results, taken together, do not provide support for an important ability to pay effect in distributional consequences of bribery in schools.

(6.3) Instrumental Variables Estimates of the Effects of Poverty ("Being Poor and Living in a Poor Village")

In this subsection, we discuss the estimates using long-term rainfall variations across villages. The estimates represent the causal effect of a household's economic status, i.e., $\left(\beta_{T}\right)$, and represent the combined "poor people" and "poor area" effects.

The 2SLS estimates are reported in Table 3, and the presentation of the results follow that in Table 2. The conclusions do not depend on the exact time window (2000-2009) used for defining the long-term rainfall instrument; see Table 4 for estimates with a different time window (20052009). The results and conclusions are similar if we use the Rivers and Vuong (1988) two-step conditional maximum likelihood estimator for the propensity to pay estimates (reported in the online appendix).

The first striking observation that comes across from Table 3 is that household permanent income has a consistently negative, statistically significant, and numerically substantial effect on 
the aggregate propensity to pay bribes for children's schooling, providing strong evidence that bribery in schools is regressive at the extensive margin. As discussed in the theoretical section above, this contradicts any model based on the following set of assumptions: (i) the returns to education is higher for the rich, and their ability to pay is higher, (2) the school official maximizes her income, (3) the official can use costly testing to screen in the rich (or screen out the poor), and (4) the punishment for corruption does not depend on household characteristics.

The disaggregated estimates in columns (2)-(4) show that the effect observed in aggregate propensity to pay is driven by bribery for admission into schools and payments with receipts; the estimates are not statistically significant at the 10 percent level for payments without receipt. When compared to the corresponding OLS estimates in Table 1, the estimates, especially for propensity to pay bribes for admission and payments with receipt, are numerically much larger. For example, the estimate for admission is -0.15 using long-term rainfall IV, while it is only -0.0084 according to the OLS estimate. This vindicates the worry that the OLS estimates are biased towards finding less regressive effects of household income.

Perhaps, the most striking result in Table 3 relates to the effects of household permanent income on the amount paid as bribes. In contrast to a statistically significant positive effect found in all of the OLS estimates in Table 1, the long-term rainfall IV estimates show that the effect is not statistically significant at the 10 percent level, and this conclusion is robust across three different specifications. The estimates in Table 3 thus suggest strongly that, among those who end up paying bribes, the poor pay the same amount for educational services as the rich do. This has important implications: (i) it rejects the model based on bargaining power as deterrence, and provides support for the refusal to pay model, (ii) it is not consistent with any model where the school teacher is able to use screening device to reveal ability to pay in a separating equilibrium, and (iii) it implies that bribes are regressive at the intensive margin, because a constant amount irrespective of income implies that the poor pay higher as a share of their income.

\section{Understanding the Mechanisms}

The focus of our analysis is to understand the effects of poverty on vulnerability to corruption in the context of bribery in schools. As discussed in details above, the effects captured by the parameter $\beta_{T}$ include a variety of mechanisms, and the evidence in Tables (2) and (3) are useful 
in sorting out the relative roles played by the different mechanisms. From Table (2), we find that the ability to pay effect is approximately zero, i.e., $\beta_{2}=0$. A comparison of the estimates in the top and middle panels of Table (3) suggest that the role played by moral costs heterogeneity is limited; the estimated effect of permanent income on the aggregate bribe propensity declines marginally from -0.139 to -0.133 when we control for moral cost heterogeneity in the regression, and the estimates of the effects on the propensity to pay bribes for admission remain virtually identical. This can be interpreted as suggestive evidence that $\beta_{M} \rho_{1} \bumpeq 0$. To understand the importance of weak enforcement regimes in poor villages, it is instructive to compare the estimates at the top panel of Table 3 (without controls for enforcement heterogeneity) with those in the bottom panel (includes controls for enforcement heterogeneity). The estimated income effect for aggregate bribing propensity declines from -0.139 to -.0 .129 , which implies that the effects of enforcement heterogeneity is larger than that of moral costs heterogeneity. But the effects in the case of bribery for admission is again zero, similar to the case of moral cost heterogeneity.

As discussed earlier, it is not possible to check the sensitivity of the estimates by including indicators of ability such as education, as they are highly correlated with permanent income and would wipe-off much of the causal effect we are interested in. Thus the estimated effect of permanent income using long-term rainfall variations represent the combined effect of "pure bargaining power" and any endogeneous response of ability. However note that we expect $\beta_{A} \tau_{1}>$ 0 , because $\beta_{A}>0$ (higher ability implies higher returns to education and more willingness to pay), and $\tau_{1}>0$ (higher ability implies higher income which improves nutrition and health leading to higher ability). ${ }^{23}$ Thus the estimates negative effect of permanent income should be interpreted as a lower bound estimate of the "pure bargaining power effect".

\section{(7) Discussion on the IV Estimates}

\section{(7.1) Interpretation of the IV Estimates}

Since we exploit variations in the rainfall for identification, one might argue that the IV estimates are relevant only for those households whose income primarily depends on the agricultural sector (land owners and agricultural wage laborers). However, flood in a village not only affects the agricultural sector, it also affects the income in the rural non-farm sector adversely, as the

\footnotetext{
${ }^{23}$ The recent evidence shows that poverty affects the development of brain of a child in a significant way (see Noble et al. (2015)).
} 
demand for non-farm products goes down. The IV estimates are thus likely to be relevant for the vast majority of the households in the villages and small towns in Bangladesh.

\section{(7.2) Magnitudes of the Effects}

The parameter estimates in Tables 1-3 provide marginal effects of an increase in income by a unit (by 1000 taka since income is expressed in thousand taka) but they are sensitive to the unit of measurement of income. To provide a sense of the magnitude of the effects, we compute elasticities at the mean values of income and relevant propensity to pay bribe. The average per capita monthly income in our sample is around $\$ 28$ and 1 percent increase in income is thus equivalent to 28 cent increase. According to the estimates in Table 3, the largest effect of an increase in income by one percent is found for propensity to pay bribe for admission. When considering total causal effects of household income (i.e., the estimate of the parameter $\beta_{T}$ using long term rainfall as IV), a 1 percent increase in income reduces propensity to pay bribe for admission by 3.32 percent, for payments with receipt by 1.80 percent and for payments without receipt by 0.46 percent. The decline in aggregate propensity to pay bribe is about 0.61 percent.

\section{(8) Conclusions}

This paper provides a theoretical and empirical analysis of distributional effects of corruption in schools in developing countries where law enforcement is not impersonal or unbiased. We develop three alternative models based on contrasting assumptions regarding the nature of enforcement regime and the information set of the corrupt official. The empirical analysis yields both substantive and methodological insights. The IV estimates using short-term rainfall shock show that the canonical ability to pay model is not supported by the evidence. We provide estimates of the effects of "being poor and living in a poor village" on bribery in schools by exploiting long-term rainfall differences across villages. The results show that corruption in schools is regressive both at the extensive and intensive margins. We find that the amount paid does not vary significantly with household income which rejects the ability to pay model, screening models with separating equilibrium under unbiased enforcement, and a version of the bargaining power model under biased enforcement that assumes that the official observes household level income (or wealth). The evidence on both the intensive and extensive margins is consistent with

the "refusal to pay model" where the official does not observe household level income (cannot 
use screening to reveal that information), and the bargaining power of a household manifests itself as "power to say no" once a bribe demand is made.

The empirical analysis also suggests that the OLS estimates of the effects of household income on propensity to pay bribes and the amount paid are significantly biased towards finding less regressive or even spurious progressive effects. The evidence and the analysis in this paper has important implications for understanding the often conflicting evidence on distributional effects of corruption on households found in the existing literature based on OLS regressions, as discussed in the literature review section above. While the evidence of regressive effects found in OLS regressions are likely to be valid (although magnitudes are underestimated), the progressive effects found in many existing OLS based studies may be driven largely by biases due to omitted ability and preference heterogeneity.

The recent evidence shows that intergenerational correlation in schooling, a standard measure of immobility in education, does not show any improvements in a large number of developing countries over the last few decades (Hertz et al. (2007), Emran and Shilpi (2015)). In fact, in the case of Bangladesh, Hertz et al. (2007) find that intergenerational educational mobility has worsened over the years. This widening inequality in educational opportunity may seem difficult to reconcile with the standard theory developed by Becker and Tomes (1979) and Solon (2004), according to which policies such as free schooling should improve educational mobility and reduce inequality. Our analysis points to corruption in schools as a potentially important factor behind the persistence of educational immobility and inequality. Even though schooling is supposed to be free (or highly subsidized) for the poor to make the 'playing field' level, the evidence presented in this paper suggests that the burden of bribery in schools falls disproportionately on the poor households, and skews the 'playing field' against them.

\section{APPENDIX}

\section{Proof of Testable Prediction (T.2)}

Given the assumptions that the poorest do not have any bargaining power and the richest can punish the teacher with certainty, it follows that there exists a threshold $y^{M}<\bar{y}$, such that 
the following equality holds (assuming that the teacher maximizes expected income):

$$
\left\{1-\hat{\delta}\left(y^{M}\right)\right\}\left[B^{*}\left(y^{M}\right)+w\right]=w
$$

It is easy to check that the expected income from bribery $\{1-\hat{\delta}(y)\}\left[B^{*}(y)+w\right]$ is a decreasing function of income if the bargaining power effect of income is strong enough in following sense:

$$
\hat{\delta}^{\prime}(y)>\frac{B^{*^{\prime}}(y)(1-\hat{\delta}(y))}{\left[B^{*}(y)+w\right]}
$$

Thus equation (13) and inequality (14) imply together that when the bargaining effect of income is strong enough to satisfy inequality (14), $\forall y_{i}>y^{M}$, the following inequality holds:

$$
\left\{1-\hat{\delta}\left(y_{i}\right)\right\}\left[B^{*}\left(y_{i}\right)+w\right]<w
$$

When inequality (15) is satisfied, it is optimal for the teacher not to ask for bribes facing a household with income $y_{i}>y^{M}$.

\section{References}

Rose-Ackerman, S (2010), "The Law and Economics of Bribery and Extortion, Annual Review of Law and Social Science 6: 217-236 (2010).

Bandyopadhya, S. and Skoufias, E. (2012). "Rainfall variability, occupational choice, and welfare in rural Bangladesh," Policy Research Working Paper Series 6134, The World Bank.

Banerjee, A.V., R. Hanna, and S. Mullainathan (2012): "Corruption," , the Handbook of Organizational Economics, edited by Robert Gibbons and John Roberts, 1109-1147. Princeton University Press.

Bardhan, P. (1997): "Corruption and Development: A Review of Issues," Journal of Economic Literature, vol. 35(3), 1320-1346.

Basu, Kaushik, Bhattacharya, Sudipto and Mishra, Ajit, 1992. "Notes on bribery and the control of corruption," Journal of Public Economics", Elsevier, vol. 48(3), pages 349-359, August.

Becker G. S. and N. Tomes (1979), "An Equilibrium Theory of the Distribution of Income 
and Intergenerational Mobility," Journal of Political Economy, vol. 87, no. 6.

Bertrand, M., Djankov, S., Hanna, R. and S. Mullainathan (2007). "Obtaining a Driver's License in India: An Experimental Approach to Studying Corruption." The Quarterly Journal of Economics, 122(4): 1639-1676, November.

Black, S., P. Devereux, and K. Salvanes (2009), Like Father Like Son? A Note on the Intergenerational Transmission of IQ Scores, Economics Letters, 105, 138-140.

Corbin, C \& James J. Heckman, 2016. "Capabilities and Skills," Working Papers 2016-018, Human Capital and Economic Opportunity Working Group.

Currie, Janet, and Douglas Almond. 2011. "Human Capital Development Before Age Five." In Handbook of Labor Economics, edited by Orley C. Ashenfelter and David Card, 1315-1486. Amsterdam: Elsevier B. V.

Di Tella, R. and Schargrodsky, E. (2004). "Do Police Reduce Crime? Estimates Using the Allocation of Police Forces after a Terrorist Attack.", American Economic Review, 94(1), 115133.

Emran, M. Shahe and Z. Hou (2013), "Access to Markets and Rural Poverty: Evidence from Household Consumption in China,"Review of Economics and Statistics, May, 2013.

Emran, M. Shahe \& Shilpi, Forhad, 2015. "Gender, Geography, and Generations: Intergenerational Educational Mobility in Post-Reform India," World Development, Elsevier, vol. 72(C), pages 362-380.

Emran, M Shahe, \& Forhad Shilpi, 2011. "Intergenerational Occupational Mobility in Rural Economy: Evidence from Nepal and Vietnam," Journal of Human Resources, University of Wisconsin Press, vol. 46(2), pages 427-458.

Ferraz, C. and Finan, F. (2008) "Exposing Corrupt Politicians: The Effects of Brazil's Publicly Released Audits on Electoral Outcomes." The Quarterly Journal of Economics, 123(2): 703-745.

Ferraz, C., Finan, F. and Moreira, D.B. (2012). "Corrupting Learning: Evidence from Missing Federal Education Funds in Brazil", Journal of Public Economics 96 (9-10): 712-726.

Fisman, R. and Svensson, J. (2007). "Are corruption and taxation really harmful to growth? Firm level evidence.", Journal of Development Economics, 83(1): 63-75.

Hertz, T, Jayasundera, T., Piraino, P., Selcuk, S., Smith, N. and Verashchagina, A. (2007), 
"The Inheritance of Educational Inequality: International Comparisons and Fifty-Year Trends", The B.E. Journal of Economic Analysis and Policy. Volume 7, Issue 2, Pages 1935-1682,

Hsieh ,C.R and Moretti, E. (2006)."Did Iraq Cheat the United Nations? Underpricing, Bribes, and the Oil for Food Program.' The Quarterly Journal of Economics, 121(4):1211-1248.

Hunt, J. and S. Laszlo (2012): "Is Bribery Really Regressive? Bribery's Costs, Benefits and Mechanisms", World Development, 40 (2), 355-372.

Hunt, J. (2007). "How corruption hits people when they are down," Journal of Development Economics, vol. 84(2), pages 574-589.

Kaufmann, D., S. Pradhan and R. Ryterman (1998), New Frontiers in Diagnosing and Combating Corruption". World Bank PREM Notes: Public Sector, October (1998).

Kaufmann, D., Judit M. and F. Recanatini (2005). "How Does Bribery Affect Public Service Delivery? Micro-evidence from Service Users and Public Officials in Peru". World Bank working paper 4492 .

Kolesár, M, Raj Chetty, John N. Friedman, Edward L. Glaeser \& Guido W. Imbens, 2014. "Identification and Inference with Many Invalid Instruments," NBER Working Papers 17519, National Bureau of Economic Research, Inc.

Mocan, N (2008), "What Determines Corruption? International Evidence From Micro Data", Economic Inquiry, 46(4): 493-510.

Mullainathan, S, and E Shafir (2013), Scarcity: Why having Too Little Leans So Much, Harvard University Press.

Noble, Kimberly G and others (2015), "Family income, parental education and brain structure in children and adolescents", Nature Neuroscience, 18, pages 773778 (2015).

Olken, B. (2006). "Corruption and the Costs of Redistribution: Micro Evidence from Indonesia.' Journal of Public Economics, 90(4-5):853-870.

Olken, B. (2007). "Monitoring Corruption: Evidence from a Field Experiment in Indonesia." Journal of Political Economy, 115: 200-249.

Olken, B. (2009). "Corruption Perceptions vs. Corruption Reality." Journal of Public Economics 93, (7-8): 950-964.

Olken, B. and Barron, P. (2009). "The Simple Economics of Extortion: Evidence from Trucking in Aceh." Journal of Political Economy, 117(3): 417-452. 
Olken, B., and R. Pande (2011). "Corruption in Developing Countries", Abdul Latif Jameel Poverty Action Lab.

Plomin, R., and F. Spinath (2004), "Intelligence: Genetics, Genes, and Genomics, Journal of Personality and Social Psychology, 86:1, 112-129.

Rajan, R and Arvind Subramanian (2008), "Aid and Growth: What Does the Cross-Country Evidence Really Show?," The Review of Economics and Statistics, MIT Press, vol. 90(4), pages 643-665, November.

Reinikka, R. and Svensson, J. (2004). "Local Capture: Evidence From a Central Government Transfer Program in Uganda." The Quarterly Journal of Economics, 119(2): 679-705.

Rose-Ackerman, Susan (2010), "The Law and Economics of Bribery and Extortion,' Annual Review of Law and Social Science 6: 217-236 (2010).

Rose-Ackerman, Susan (1978). Corruption: A Study in Political Economy. New York: Academic Press, 1978.

Sequeira, S. and Djankov, S. (2010), An Empirical Study of Corruption in Ports, SSRN WP.

Svensson, Jakob, (2003). "Who Must Pay Bribes and How Much? Evidence from A Cross Section of Firms". The Quarterly Journal of Economics 118 ( 1), 207-230.

World Bank (2010), Silent and Lethal How Quiet Corruption Undermines Africa's Development Effort, IBRD/ World Bank, Washington DC. 
Table 1: Household Income and bribery in schools (OLS Estimates)

(1)

(2)

\section{Panel A}

(3)

(4)

Propensity to pay bribe (aggregate)

\begin{tabular}{lllllc} 
Per capita income & $-0.0383 * * *$ & $-0.0363 * * *$ & $-0.0335 * * *$ & $-0.0169 * * *$ \\
& $(-8.224)$ & $(-7.970)$ & $(-7.147)$ & $(-3.791)$ \\
\hline \multicolumn{5}{c}{ Panel B } \\
Per capita income & \multicolumn{5}{c}{ Propensity to pay bribe for admission } \\
& $-0.0121^{* * *}$ & $-0.0113 * * *$ & $-0.0103 * * *$ & $-0.00791 * * *$ \\
& $(-5.333)$ & $(-5.001)$ & $(-4.468)$ & $(-2.848)$ \\
\hline \multicolumn{5}{c}{ Panel C } \\
Per capita income & \multicolumn{5}{c}{ Propensity to pay bribe with receipts } \\
& $-0.0248 * * *$ & $-0.0238 * * *$ & $-0.0224 * * *$ & $-0.0155^{* * *}$ \\
& $(-8.440)$ & $(-8.229)$ & $(-7.623)$ & $(-4.342)$ \\
\hline
\end{tabular}

Panel D

Propensity to pay bribe: Payment without receipt

\begin{tabular}{|c|c|c|c|c|}
\hline Per capita income & $\begin{array}{l}-0.0293 * * * \\
(-6.592)\end{array}$ & $\begin{array}{l}-0.0281 * * * \\
(-6.382)\end{array}$ & $\begin{array}{c}-0.0261 * * * \\
(-5.827) \\
\end{array}$ & $\begin{array}{c}-0.0107 * * \\
(-2.432) \\
\end{array}$ \\
\hline Observations & 3,605 & 3,605 & 3,605 & 3,605 \\
\hline & \multicolumn{2}{|c|}{ Total Amount paid as bribe } & & \\
\hline Per capita income & $\begin{array}{l}0.0786^{* * * *} \\
(2.831)\end{array}$ & $\begin{array}{l}0.0783^{* * * *} \\
(2.851)\end{array}$ & $\begin{array}{c}0.0762 * * * \\
(2.965)\end{array}$ & $\begin{array}{c}0.0796 * * * \\
(4.582)\end{array}$ \\
\hline Observations & 1,747 & 1,747 & 1,747 & 1,747 \\
\hline Household Level controls & Yes & Yes & Yes & Yes \\
\hline Moral Cost & No & Yes & Yes & NA \\
\hline Village level controls & & & & \\
\hline Enforcement in the Village & No & No & Yes & NA \\
\hline Village fixed effects & No & No & No & Yes \\
\hline Regional Fixed effects & Yes & Yes & Yes & NA \\
\hline
\end{tabular}

Notes: (1) Standard errors are clustered at primary sampling unit (village) level. (2) Each cell in the rows labelled per capita income represents result from a separate regression. (3) Robust $t$ statistics in parentheses

(4) * significant at $10 \%$; ** significant at $5 \%$; *** significant at $1 \%$ 
Table 2: Testing Ability to Pay Effect: Estimates with Rainfall Shock as IV (2SLS)

\begin{tabular}{|c|c|c|c|c|c|}
\hline & \multicolumn{4}{|c|}{ Propensity to Pay bribe } & \multirow{2}{*}{$\begin{array}{c}\text { Amount } \\
\text { paid as bribe }\end{array}$} \\
\hline & Aggregate & Admission & With receipt & Without Receipt & \\
\hline Per capita income & $\begin{array}{l}-0.0401 \\
(-0.447)\end{array}$ & $\begin{array}{l}-0.0777 \\
(-1.449)\end{array}$ & $\begin{array}{l}-0.0675 \\
(-1.204)\end{array}$ & $\begin{array}{l}-0.0176 \\
(-0.196)\end{array}$ & $\begin{array}{l}0.0797 \\
(0.507)\end{array}$ \\
\hline First stage F Statistic & 11.60 & 11.60 & 11.60 & 11.60 & 9.075 \\
\hline \multicolumn{6}{|c|}{ Controls for Moral Cost Heterogeneity } \\
\hline Per capita income & $\begin{array}{l}-0.0321 \\
(-0.364)\end{array}$ & $\begin{array}{l}-0.0754 \\
(-1.400)\end{array}$ & $\begin{array}{l}-0.0642 \\
(-1.144)\end{array}$ & $\begin{array}{l}-0.0125 \\
(-0.139)\end{array}$ & $\begin{array}{l}0.0807 \\
(0.518)\end{array}$ \\
\hline First stage F Statistic & 11.68 & 11.68 & 11.68 & 11.68 & 9.109 \\
\hline \multicolumn{6}{|c|}{ Controls for village Enforcement Heterogeneity } \\
\hline Per capita income & $\begin{array}{l}-0.00888 \\
(-0.0976)\end{array}$ & $\begin{array}{l}-0.0727 \\
(-1.284)\end{array}$ & $\begin{array}{l}-0.0564 \\
(-0.957)\end{array}$ & $\begin{array}{l}0.00482 \\
(0.0507)\end{array}$ & $\begin{array}{l}0.0551 \\
(0.298)\end{array}$ \\
\hline First stage F Statistic & 10.13 & 10.13 & 10.13 & 10.13 & 7.726 \\
\hline $\begin{array}{l}\text { Household Level } \\
\text { controls }\end{array}$ & Yes & Yes & Yes & Yes & Yes \\
\hline Regional Fixed effects & Yes & Yes & Yes & Yes & Yes \\
\hline
\end{tabular}

Note: Standard errors are clustered at primary sampling unit (village) level. Each cell in the rows labelled per capita income represents result from a separate regression. Robust $t$ statistics in parentheses

* significant at $10 \%$; * significant at $5 \%$; *** significant at $1 \%$

Table 3: Refusal to Pay vs. Deterrence Models: Estimates with Long term Rainfall as IV

\begin{tabular}{|c|c|c|c|c|c|}
\hline & \multicolumn{4}{|c|}{ Propensity to Pay bribe } & \multirow{2}{*}{$\begin{array}{c}\text { Amount } \\
\text { paid as bribe }\end{array}$} \\
\hline & Aggregate & Admission & With receipt & Without Receipt & \\
\hline Per capita income & $\begin{array}{l}-0.139 * * \\
(-2.251)\end{array}$ & $\begin{array}{l}-0.149 * * \\
(-2.527)\end{array}$ & $\begin{array}{c}-0.143 * * * \\
(-2.647)\end{array}$ & $\begin{array}{l}-0.0853 \\
(-1.387)\end{array}$ & $\begin{array}{l}0.0334 \\
(0.388)\end{array}$ \\
\hline First stage F Statistic & 11.23 & 11.23 & 11.23 & 11.23 & 12.41 \\
\hline \multicolumn{6}{|c|}{ Controls for Moral Cost Heterogeneity } \\
\hline Per capita income & $\begin{array}{c}-0.133 * * \\
(-2.136)\end{array}$ & $\begin{array}{c}-0.148 * * \\
(-2.487)\end{array}$ & $\begin{array}{c}-0.141 * * * \\
(-2.596)\end{array}$ & $\begin{array}{l}-0.0812 \\
(-1.289)\end{array}$ & $\begin{array}{l}0.0319 \\
(0.366)\end{array}$ \\
\hline First stage F Statistic & 11.14 & 11.14 & 11.14 & 11.14 & 12.35 \\
\hline \multicolumn{6}{|c|}{ Controls for Village Enforcement Heterogeneity } \\
\hline Per capita income & $\begin{array}{c}-0.129 * * \\
(-2.058)\end{array}$ & $\begin{array}{c}-0.149 * * \\
(-2.437)\end{array}$ & $\begin{array}{l}-0.141 * * \\
(-2.551)\end{array}$ & $\begin{array}{l}-0.0779 \\
(-1.202)\end{array}$ & $\begin{array}{l}0.0336 \\
(0.365)\end{array}$ \\
\hline First stage F Statistic & 11.22 & 11.22 & 11.22 & 11.22 & 12.18 \\
\hline $\begin{array}{l}\text { Household Level } \\
\text { controls }\end{array}$ & Yes & Yes & Yes & Yes & Yes \\
\hline Regional Fixed effects & Yes & Yes & Yes & Yes & Yes \\
\hline
\end{tabular}

Note: Standard errors are clustered at primary sampling unit (village) level. Each cell in the rows labelled per capita income represents result from a separate regression. Robust $\mathrm{t}$ statistics in parentheses

$*$ significant at $10 \% ; * *$ significant at $5 \%$; ** significant at $1 \%$ 
Table 4: Refusal to Pay vs. Deterrence Models (Robustness Checks for IV Estimates) Panel A: Estimates from 2005-2009 rainfall IV

\begin{tabular}{|c|c|c|c|c|c|}
\hline & \multicolumn{4}{|c|}{ Propensity to Pay bribe } & \multirow{2}{*}{$\begin{array}{c}\text { Amount } \\
\text { paid as bribe }\end{array}$} \\
\hline & Aggregate & Admission & With receipt & Without Receipt & \\
\hline \multicolumn{6}{|l|}{ Rainfall Shock IV } \\
\hline \multirow[t]{2}{*}{ Per capita income } & -0.0115 & -0.0650 & -0.0495 & -0.00174 & 0.0641 \\
\hline & $(-0.124)$ & $(-1.190)$ & $(-0.849)$ & $(-0.0180)$ & $(0.358)$ \\
\hline First stage F Statistic & 10.16 & 10.16 & 10.16 & 10.16 & 8.497 \\
\hline \multicolumn{6}{|c|}{ Long-term Rainfall IV } \\
\hline \multirow[t]{2}{*}{ Per capita income } & $-0.116^{*}$ & $-0.142 * *$ & $-0.119 * *$ & -0.0770 & 0.0654 \\
\hline & $(-1.716)$ & $(-2.258)$ & $(-2.196)$ & $(-1.107)$ & $(0.632)$ \\
\hline First stage F Statistic & 10.19 & 10.19 & 10.19 & 10.19 & 9.576 \\
\hline
\end{tabular}




\title{
Online Appendix (Not for Publication): Distributional Effects of Corruption When Enforcement is Biased: Theory and Evidence from Bribery in Schools in Bangladesh
}

\author{
M. Shahe Emran ${ }^{1}$ \\ IPD, Columbia University \\ Asadul Islam \\ Monash University \\ Forhad Shilpi \\ World Bank
}

\section{(1) Proof of Proposition 1}

(1.a) A teacher does not ask for bribes facing a household with income $y_{i}<\tilde{y}\left(A_{H}, M_{L}\right)$ where $\tilde{y}\left(A_{H}, M_{L}\right)$ is defined by the following equation:

$$
\{1-\tilde{\delta}\}\left[B^{*}\left(\tilde{y}\left(A_{H}, M_{L}\right)\right)+w\right]=w
$$

where the maximum bribe a household $i$ is willing to pay and still send the child to school is $B_{i}^{*}$, implying that at this bribe the participation constraint (3) in the main text of the paper binds. Now note that within the subset of households $\left(A_{H}, M_{L}\right)$, the maximum bribe that can be extracted is a negative function of income, given strict concavity of the utility function. The proof then completes by the observation that $\tilde{y}\left(A_{H}, M_{L}\right)=\operatorname{Min}_{i}\left(\tilde{y}\left(A_{i}, M_{i}\right)\right)$ where $\tilde{y}\left(A_{i}, M_{i}\right)$ is defined analogously to equation (1) above.

(1.b) A household $i$ is willing to pay a positive amount of bribe and send the kid to school if $u^{\prime}\left(y_{i}\right)<q\left(A_{i}\right)-M_{i}$. Denote the income threshold $y^{L}\left(A_{H}, M_{L}\right)$ such that the

\footnotetext{
${ }^{1}$ We are grateful to Matthew Lindquist, Dilip Mookherjee, Hillary Hoynes, Jeffrey Wooldridge, Larry Katz, Rajeev Dehejia, Arif Mamun, Ali Pratik, Paul Carrillo, Virginia Robano, Rafiqul Hassan, Niaz Asadullah, Zhaoyang Hou and seminar participants at Monash University for helpful discussions and/or comments on earlier drafts. We thank Transparency International Bangladesh and Iftekhrauzzaman for access to the NHSC (2010) data used in this study. The standard disclaimer applies.
} 
following holds: $u^{\prime}\left(y^{L}\left(A_{H}, M_{L}\right)\right)=q\left(A_{H}\right)-M_{L}$. So among the households with the highest ability and lowest moral cost, any household with income $y_{i}<y^{L}\left(A_{H}, M_{L}\right)$ is unwilling to pay even an infinitesimally small positive amount of bribes. Now observe that $q\left(A_{H}\right)-M_{L}=\operatorname{Max}\left(q\left(A_{i}\right)-M_{i}\right)$. Since $u\left(y_{i}\right)$ is concave, this implies that $y^{L}\left(A_{H}, M_{L}\right)=$ $\operatorname{Min}\left(y^{L}\left(A_{i}, M_{i}\right)\right)$.

(1.c) Consider the subset of households with a given combination of ability and moral cost $A_{i}, M_{i}$. So the heterogeneity in income within the group derives from endowment differences. By implicit function theorem:

$$
\frac{\partial B_{i}^{*}\left(A_{i}, M_{i}\right)}{\partial y_{i}}=\frac{u^{\prime}\left(y_{i}-B_{i}\right)-u^{\prime}\left(y_{i}\right)}{u^{\prime}\left(y_{i}-B_{i}\right)}>0, \forall B_{i}^{*}>0 \text {, because } u(.) \text { is strictly concave. }
$$

Since the income function implies that higher ability and lower moral cost increase income given a resource endowment $E_{i}$, the teacher can extract more bribes when facing a household with high ability and low moral cost.

(1.d) A progressive bribe function implies that the elasticity of bribe amount with respect to income is greater than 1 . Thus we require:

$$
\frac{\partial B_{i}^{*}}{\partial y_{i}} \frac{y_{i}}{B_{i}^{*}}>1 \Rightarrow 1-\frac{u^{\prime}\left(y_{i}\right)}{u^{\prime}\left(y_{i}-B_{i}^{*}\right)}>\frac{B_{i}^{*}}{y_{i}}
$$

Because from (1.c) above we have:

$$
\frac{\partial B_{i}^{*}\left(A_{i}, M_{i}\right)}{\partial y_{i}}=1-\frac{u^{\prime}\left(y_{i}\right)}{u^{\prime}\left(y_{i}-B_{i}^{*}\right)}
$$

Note that the higher the second derivative of the utility function (in absolute magnitude), the more likely it is that inequality (2) above will be satisfied.

Consider the isoelastic utility function:

$$
u(c)=\left\{\begin{array}{c}
\frac{c^{1-\gamma}-1}{1-\gamma} \text { for } \gamma>0 \text { and } \gamma \neq 1 \\
\log (c) \text { for } \gamma=1
\end{array}\right.
$$


In this case, inequality (2) reduces to

$$
1-\left[\frac{\left(y_{i}-B_{i}^{*}\right)}{\left(y_{i}\right)}\right]^{\gamma}>\frac{B_{i}^{*}}{y_{i}}
$$

An inspection of the left hand side of inequality (4) shows that it reduces to $\frac{B_{i}^{*}}{y_{i}}$ when $\gamma=1$. Thus inequality (4) is violated even though utility function is concave, when $\gamma \leq 1$. To get a progressive bribe function, we require a utility function with stronger diminishing marginal utility than implied by the log function.

(2) Heavy Rainfall and Interactions Based Instruments: What Do They Represent?

We use the interactions of heavy rainfall dummy with exogeneous household characteristics as identifying instruments. The interactions as instruments exploit possible heterogeneity across households in the effects of heavy rainfall. For example, we expect that heavy rainfall (and flood) will have stronger effects on the income of those households who rely more on agriculture, such as farming households and agricultural wage laborers (unskilled labor). Thus an obvious way to introduce household heterogeneity is to interact the land owned by a a household with the heavy rainfall dummy. However, there is an important objection to this. To ensure that the exclusion restriction imposed on the interaction of rainfall is reasonable, we need to control for direct effects of land (possibly nonlinear), which would nullify a large part of the income effect we are trying to capture using rainfall variations for identification.

We thus use other indicators of household heterogeneity such as the age of the household head and religion. Both of these characteristics are clearly exogeneous in the context of Bangladesh, as religion is not a choice (determined at birth) for most people, because conversion is rare. The effects of rainfall on income may vary with the age of the household head, because a household with older head is more likely to be in agricultural occupation and thus be more exposed to rainfall shocks. Also, as noted in the manuscript, there is substantial evidence that degree of risk aversion increases with age. On the other hand, a 
household headed by younger individual will be better able to withstand a negative shock such as flood; a young individual has more energy, and is more likely to take advantage of temporary migration to nearby town in response to a negative rainfall shock. Thus we would expect heavy rainfall to have stronger negative effects on the households headed by older individuals. The heterogeneity with respect to religion may be due, for example, to differences in social capital and strength of informal risk sharing. The minority groups usually cultivate more cohesive social network, and thus are likely to have better informal risk-sharing. Also, for historical reasons, the minority groups such as Hindu's in Bangladesh are more likely to be traders and artisans, and rely less on agriculture compared to Muslims. ${ }^{2}$ However, an obvious objection to such interaction based instruments is that age and religious affiliation may have direct effect on the propensity to pay bribes. We thus control for the possible direct effect of Muslim dummy and age of the household head in the IV regressions.

\section{(3) Primary and Secondary Education in Rural Bangladesh}

The primary schooling (grades 1-5) in rural Bangladesh is dominated by public schools, although there are also private and NGO operated schools. Almost 80 percent of enrollment are into public and registered private schools. The public schools are financed by government and a large part of the financing of the private schools also come from the government. Bangladesh Government bears the 90 percent of the salary of the teachers in registered private schools and also allocates funds for improvements and maintenance of the school infrastructure. The NGO schools provide non-formal education to the poorest section of the income distribution and are primarily located in areas not served by public or private schools.

Bangladesh enacted compulsory primary education in 1990. It established a six member 'compulsory primary education committee' in the lowest tier of local government, the union (a collection of villages). The committee was to "ensure admission and regular presence of all children of the area in primary schools" (GOB, 1990). The 1990 Act also had provisions

\footnotetext{
${ }^{2}$ In our data set, Muslim households own more lands on average and also more likely to be farmers and unskilled laborers.
} 
for penalties for non-compliance. If the local committee or the parents were unable to ensure attendance of the children in the village, they could be fined up to Tk. 200. But in reality the penalty for noncompliance was not enforced. The primary schools in rural areas, public, NGO, or private, are free for every child; there is no tuition or examination fees. Government provides free books in all primary schools.

The secondary schooling (grades 6-10) infrastructure is dominated by 'private schools', public schools play a smaller role. However, most of the 'private secondary schools' (registered ones) are primarily financed by the government, including teacher salary, and capital spending, maintenance and repair of the schools. Tuition fees are charged in most of the secondary schools, but the cost of education is lower in the religious secondary schools (Education Watch, 2005). Books are freely distributed by government in all secondary schools. In January 1994, stipend was introduced for girls attending secondary schools. Under the girls' stipend program, all girls in rural areas who enter secondary school are eligible for a monthly sum ranging from 25 taka in grade 6 to 60 taka in grade 10 . They also receive additional payments for new books. Three conditions need to be met for receiving stipend: (i) a minimum of 75 percent attendance rate, (ii) at least a 45 percent score in annual school exams, and (iii) staying unmarried until sitting the Secondary School Certificate or turning 18. The girls stipend program seems to have a strong effect and the girls enrollment in secondary schools have increased substantially in recent years.

Net enrollment rates in primary schools for boys and girls were 83 percent and 81 percent in 1996, and 84 and 96 percent in 2004. Quality of education is in general low, and grade repetition and drop outs are major problems. The survival rate in primary school was 55.3 percent in 1991 and 53.5 percent in 2004, showing little improvements. The net enrollment rate in secondary schools was 38 percent for boys and 50 percent for girls in 2005 (Education Watch, 2005). There is clear evidence that poor households are at a disadvantage: the net enrollment rate in secondary schools was 25 percent for food deficit households and 59 percent for food surplus households. 
References not cited in the manuscript

(1) Ahmed, M, K. S. Ahmed, N. I. Khan and R. Ahmed (2008), "Access to Education in Bangladesh: Country Analytic Review of Primary and Secondary Education", Report for CREATE, BRAC Dhaka, Bangladesh.

(2) World Bank (2008), Education for All in Bangladesh: Where Does Bangladesh Stand in Achieving the EFA Goals by 2015? Bangladesh Development Series Paper No. 24, April 2008.

(3) Education Watch (2005), The State of Secondary Education: Progress and Challenges, Dhaka, Bangladesh. 


\section{Appendix Tables}

Table A.1: Summary Statistics

\begin{tabular}{|c|c|c|c|c|c|}
\hline Variables & Obs & Mean & Std. Dev. & Min & Max \\
\hline \multicolumn{6}{|l|}{ Propensity to pay bribe } \\
\hline All including payment w/o receipts & 3605 & 0.48 & 0.50 & 0.00 & 1.00 \\
\hline For Admission & 3605 & 0.10 & 0.30 & 0.00 & 1.00 \\
\hline For Scholarship payments & 3605 & 0.04 & 0.20 & 0.00 & 1.00 \\
\hline All excluding payment w/o receipts & 3605 & 0.18 & 0.38 & 0.00 & 1.00 \\
\hline Payment w/o receipts & 3605 & 0.40 & 0.49 & 0.00 & 1.00 \\
\hline Amount of bribe paid annually ('000 Taka) & 1747 & 0.25 & 1.00 & 0.01 & 28.48 \\
\hline $\begin{array}{l}\text { Share of per capita monthly income paid as bribe } \\
\text { Monthly Per Capita household income (PCI) ('000 }\end{array}$ & 1747 & 0.14 & 0.35 & 0.00 & 7.01 \\
\hline Taka) & 3605 & 2.30 & 1.97 & 0.20 & 31.83 \\
\hline PCI of households paying bribe ('000 Taka) & 1747 & 1.95 & 1.58 & 0.20 & 16.00 \\
\hline PCI of households not paying bribe ('000 Taka) & 1858 & 2.62 & 2.23 & 0.40 & 31.83 \\
\hline Rainfall (mean over last 10 years) (milimetre) & 3605 & 1592 & 417 & 1009 & 3299 \\
\hline Deviation of 2009 Rainfall from its 10 year mean & 3605 & 125 & 78 & -674 & 1480 \\
\hline \multicolumn{6}{|l|}{ Household Characteristics } \\
\hline Head's education (years) & 3605 & 9.67 & 3.81 & 0.00 & 18.00 \\
\hline Landownership (Acre) & 3605 & 1.40 & 2.41 & 0.00 & 38.06 \\
\hline Membership and connection & 3605 & 0.46 & 0.67 & 0.00 & 3.00 \\
\hline Propensity to pay bribe for non-educational services & 3605 & 0.38 & 0.35 & 0.00 & 1.00 \\
\hline Household size & 3605 & 5.85 & 2.18 & 2.00 & 21.00 \\
\hline No. of School age children & 3605 & 2.10 & 1.05 & 1.00 & 7.00 \\
\hline Age of Head & 3605 & 49.25 & 13.13 & 18.00 & 110.00 \\
\hline Head female & 3605 & 0.12 & 0.33 & 0.00 & 1.00 \\
\hline Head Muslim & 3605 & 0.86 & 0.35 & 0.00 & 1.00 \\
\hline \multicolumn{6}{|l|}{ Village Level Variables } \\
\hline Per capita Expenditure (taka) & 3605 & 1714 & 640 & 660 & 4684 \\
\hline Av. Propn. To pay bribe for non-educational services & 3605 & 0.28 & 0.12 & 0.05 & 0.64 \\
\hline
\end{tabular}

Data Source: National Household Survey on Corruption (NHSC), 2010 
Table A.2: Rivers and Vuong (1988) CMLE Estimates for Propensity to Pay Bribes

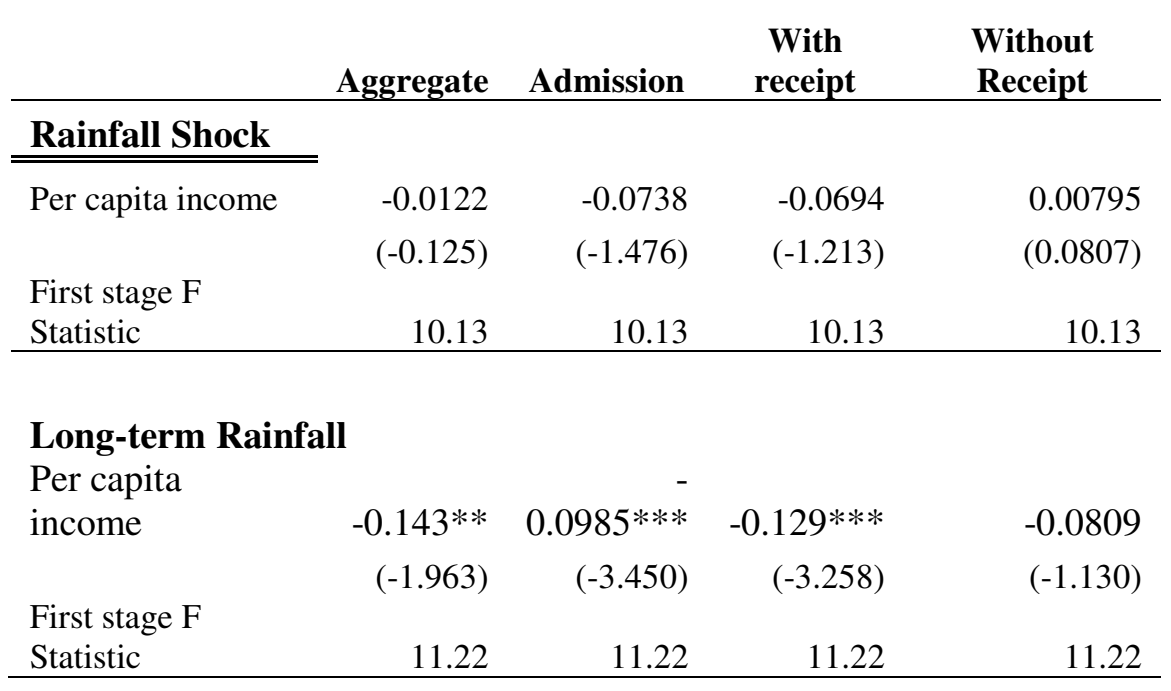

